\title{
Novel Strategies for Upstream and Downstream Processing of Tannin Acyl Hydrolase
}

\author{
Luis V. Rodríguez-Durán, ${ }^{1}$ Blanca Valdivia-Urdiales, ${ }^{1}$ Juan C. Contreras-Esquivel,, 2 \\ Raúl Rodríguez-Herrera, ${ }^{1}$ and Cristóbal N. Aguilar ${ }^{1}$ \\ ${ }^{1}$ Food Research Department, School of Chemistry, Autonomous University of Coahuila, Boulevard V. Carranza and González Lobo s/n, \\ 25280 Saltillo, Coahuila, Mexico \\ ${ }^{2}$ Research and Development Center, Coyotefoods Biopolymer and Biotechnology Co., Simón Bolivar 851-A, 25280 Saltillo, \\ Coahuila, Mexico
}

Correspondence should be addressed to Cristóbal N. Aguilar, cristobal.aguilar@uadec.edu.mx

Received 28 April 2011; Accepted 9 July 2011

Academic Editor: Alane Beatriz Vermelho

Copyright ( $\odot 2011$ Luis V. Rodríguez-Durán et al. This is an open access article distributed under the Creative Commons Attribution License, which permits unrestricted use, distribution, and reproduction in any medium, provided the original work is properly cited.

\begin{abstract}
Tannin acyl hydrolase also referred as tannase is an enzyme with important applications in several science and technology fields. Due to its hydrolytic and synthetic properties, tannase could be used to reduce the negative effects of tannins in beverages, food, feed, and tannery effluents, for the production of gallic acid from tannin-rich materials, the elucidation of tannin structure, and the synthesis of gallic acid esters in nonaqueous media. However, industrial applications of tannase are still very limited due to its high production cost. Thus, there is a growing interest in the production, recovery, and purification of this enzyme. Recently, there have been published a number of papers on the improvement of upstream and downstream processing of the enzyme. These papers dealt with the search for new tannase producing microorganisms, the application of novel fermentation systems, optimization of culture conditions, the production of the enzyme by recombinant microorganism, and the design of efficient protocols for tannase recovery and purification. The present work reviews the state of the art of basic and biotechnological aspects of tannin acyl hydrolase, focusing on the recent advances in the upstream and downstream processing of the enzyme.
\end{abstract}

\section{Introduction}

Tannin acyl hydrolase also known as tannase is an enzyme (EC 3.1.1.20) that catalyzes the hydrolysis of ester bonds present in gallotannins, complex tannins, and gallic acid esters $[1,2]$. Tannase has several important applications in food, feed, chemical and pharmaceutical industries, but high scale use of this enzyme is severally restricted due to high production costs $[3,4]$.

Thus, there is a growing interest on basic and applied aspects of tannase. In the last decade, there have been a number of efforts to improve the production, recovery, and purification processes of the enzyme. These efforts include the looking for new tannase sources [5-12], the development of novel fermentation systems [13-15], the optimization of culture conditions [16-19], the production of the enzyme by recombinant microorganism [20-24], and the design of efficient protocols for tannase recovery and purification [25-27].
Technological advances on tannase processing must be supported by basic investigation. The induction and repression systems have been studied in submerged- $(\mathrm{SmF})$ and solid-state fermentation systems (SSF) [28, 29]; the physicochemical properties of several tannases have been characterized $[7,12,20,30-35]$, and there have been a special interest in the description of tannase and tannase gene structure $[21,36-44]$.

The present work reviews the state of the art of basic and biotechnological aspects of tannin acyl hydrolase, focusing on the recent advances in the upstream and downstream processing of the enzyme.

\section{Tannase Substrate: Tannins}

Tannins are natural polyphenolic compounds that are widely distributed in several parts of vascular plants. They are 
the second most abundant group of phenolics in nature and are considered as secondary metabolic compounds of plants because they play no direct role in plant metabolisms [9]. Tannins are characterized by their ability to form strong complexes with different minerals and macromolecules, such as proteins, cellulose, and starch among others [45]. Due to their strong ability to bind with proteins, they have been used for tanning for thousands of years [46].

Tannins have several interesting biological activities. Active principles of medicinal plants are often polyphenolic compounds, and, in recent years, there has been a great scientific interest for this group of compounds due to their antioxidant, antiviral, and anticancer properties [47, 48]. In traditional medicine of China and Japan, the plant extracts rich in tannins have been used as astringent, antidiarrheal, diuretic, anti-inflammatory, antiseptic, and antihemorrhagic agents. Similarly for their ability to precipitate heavy metals and some alkaloids, tannins can be used in the treatment of poisoning caused by these substances [49].

In the other hand, presence of tannins in the diet of ruminants affects their growth and milk production in different ways. Interaction of tannins with macromolecules form complexes that interfere with digestion of certain nutrients, digestive enzymes in saliva and rumen, and thereby reduce the degradation of nutrients. In addition, tannins impart a bitter taste, and this could significantly reduce the feed intake by livestock [50, 51].

High concentrations of tannins in beverage such as iced tea, beer, wine, fruit juices, and coffee-flavored beverages can result in the formation of precipitates due to their interaction with other molecules present in these beverages. These undesirable effects of tannins can be reduced or eliminated by a chemical or enzymatic treatment $[50,52]$.

Tannins are resistant to biodegradation, and the accumulation due to discharge of tanneries and coffee-processing industries effluents can result in environmental pollution $[53,54]$. Tannins are toxic to fungi, bacteria, and viruses. However, many microorganisms have developed the mechanisms to overcome the effects of tannins. These mechanisms include tannin modification, degradation, dissociation of tannin-substrate complexes, tannin inactivation by highaffinity binders, membrane modification, and metal ion sequestration [8]. Tannase is involved in the biodegradation of tannins and is an ecologically important biocatalyst.

\section{Basic Aspects of Tannin Acyl Hydrolase}

As previously mentioned, tannase catalyzes the hydrolysis of ester and depside bonds present in gallotannins, complex tannins, and gallic acid esters $[1,2]$ but do not affect the carbon-carbon bonds, thus tannase is unable to hydrolyze condensed tannins [55].

It is well known that tannase catalyzes the hydrolysis of tannic acid (nonagalloyl glucose) to nine molecules of gallic acid and one molecule of glucose, but the mechanism and the intermediary compounds are not clearly understood.

3.1. Substrate Specificity. It has been a matter of dispute whether the esterase and depsidase activities of microbial tannases were due to two separate enzymes or to only one enzyme catalyzing both reactions [56]. Toth and Barsony [57] proposed that tannase activity is composed by two separated enzymes: a "depsidase" that hydrolyzes the depside bonds (galloyl ester of gallic acid) and an "esterase" that catalyzes the cleavage of ester (galloyl ester of an alcohol moiety). Later, Haslam and Stangroom reported that the esterase/depsidase ratio of Aspergillus niger tannase may be modified by cultural methods and isolation procedures, suggesting the presence of two different enzymes. But further analysis indicated that esterase and depsidase are isoenzymes with low specificities capable of hydrolyzing both esters and depsides of gallic acid but with different relative specificity for each substrate [55]. Beverini and Metche [58] isolated two separate isoenzymes, tannase I and tannase II from A. oryzae, with esterase and depsidase activity, respectively. But several other authors have purified tannases with both esterase and depsidase activity $[20,21,59]$.

Studies on the regulation of tannase indicated that the enzyme would react with any phenolic hydroxyl group [60]. But, for the formation of a true enzyme-substrate complex, the substrate has to be an ester compound of gallic acid, although there is no restriction on the structure of an alcohol composing a substrate ester. These studies also indicated that the ester or carboxyl does not link to the enzyme by itself, since an ester or carboxylic compound is not hydrolyzed by or inhibits the enzyme unless it has phenolic hydroxyls [24]. Further studies revealed that esters of protocatechuic acid (3,4-dihydroxybenzoic acid) can also be hydrolyzed by tannase $[20,61]$. An exceptional case is a tannase analogue extracted from pedunculate oak (Quercus robur) leaves. This plant tannase is an unspecific esterase, capable of hydrolyzing simple galloyl esters (methyl, ethyl, and propyl gallate). naphthyl acetate, mono- to hexa-substituted galloyl$\beta$-D-glucoses, variously ring-substituted 1-O-benzoyl- $\beta$-Dglucoses and with depsides like meta-digallic acid or chlorogenic acid [56].

On the other hand, a few bifunctional tannases have been reported. Ramírez-Coronel and coworkers found an Aspergillus niger tannase with sequence similarity to an A. kawachi $\beta$-glucosidase. Purified tannase was capable to hydrolyze cellobiose efficiently. However, no $\beta$-glucosidase activity was detected when the enzyme was assayed in the presence of tannic acid [42]. García-Conesa et al. [62] found an $A$. oryzae capable to hydrolyze several synthetic diethyl diferulates. The efficiency of this esterase activity on most diferulates is low compared to that of a cinnamoyl esterase, FAEA, from $A$. niger.

Summarizing, tannases are a group of esterases with more or less specificity for a substrate. This specificity depends on the source and the methods utilized for its production and isolation. Additionally, it is evident that, from a certain organism, several tannase isoenzymes with different substrate affinity could be isolated.

3.2. Mechanism of Action. Tannase completely hydrolyzes tannic acid to gallic acid and glucose. Iibuchi et al. [60] studied the intermediary compounds formed during this hydrolysis by thin layer chromatography. They found the formation 
of 2,3,4,6-tetragalloylglucose, two kinds of monogalloylglucose and free gallic acid. They detected the same products in the hydrolysate of 1,2,3,4,6,-pentagalloylglucose. With this information they proposed a degradation pathway (Figure 1).

Tannase hydrolyzes other substrates such as methyl gallate, propyl gallate, digallic acid, epicatechin gallate, and epigallocatechin gallate-releasing gallic acid [20,63]. Tannase also acts on ellagitannins such as rosacyanin or phyllanemblinin. In those cases, tannase selectively hydrolyses the galloyl moieties, yielding gallic acid and degalloylated ellagitannins $[64,65]$. These reactions are illustrated in Figures 2 and 3.

3.3. Physicochemical Properties. One of the most studied topics on tannase is that related to its physicochemical properties. Several fungal, bacterial, and plant tannases have been purified and characterized. Important differences have been found between characterized tannases. These differences are related to the organism that produced the enzyme, the source of the organism, and the production conditions [4].

All known tannases are serine esterases, as inferred from inhibition studies with phenyl-methyl-sulfonyl fluoride (PMSF) and diisopropyl fluorophosphate (DFP) [31, 32, 37, 59] and the presence of the pentapeptide motif (-Gly-X-Ser$\mathrm{X}-\mathrm{Gly}-)$ in the sequence of tannase gene [21, 66]. However, literature reveals that the protein tannase is very diverse in its structural properties (Table 1).

The molecular weight of characterized tannases was found to be in the range of $50-320 \mathrm{kDa}[21,32,40,43,69]$ depending on the source. Most of fungal tannases have been reported to be multimeric proteins formed by 2 to 8 subunits. For example, Ramírez-Coronel et al. [42] purified and characterized an Aspergillus niger tannase which is active in monomeric and dimeric isoforms of 90 and $180 \mathrm{kDa}$, respectively; Böer and coworkers found that tannase from the dimorphic yeast Arxula adeninivorans is composed homotetramer with subunits of $80 \mathrm{kDa}$ [21]; Beena et al. reported a tannase of A. awamori formed by six identical subunits of $37.8 \mathrm{kDa}$ [37]; otherwise, Hatamoto et al. reported that native tannase of $A$. oryzae consists of four pairs of two types of subunits ( 30 and $34 \mathrm{kDa}$, resp.) linked together by disulfide bonds, forming a heterooctamer of $310 \mathrm{kDa}$ [43]. Furthermore, all bacterial tannases characterized are monomeric with a molecular weight ranging from 50 to $90 \mathrm{kDa}[39,40$, 68].

All fungal and yeast tannases are glycoprotein with a variable content of carbohydrate ranging from 5.4 to $64 \%$ [12, $21,37,58,59,67,70,71]$. On the contrary, bacterial tannases seems not to present such posttranslational modifications $[40,68]$. Tannase glycosylations consist primarily of neutral sugars like mannose, galactose, and hexosamines [24].

The biological function of this high carbohydrate content is unknown but may be related to ability to tolerate the denaturing action of tannin [52]. The carbohydrate coating probably protects the polypeptide backbone, which would then be less accessible to tannin molecules. Consequently, binding of tannin by glycoprotein probably occurs with the carbohydrate rather than with the protein, perhaps creating a weaker and more readily reversible complex. This hypothesis is supported by the observation that tannase and other tannin-resistant proteins are glycoprotein with a high content of carbohydrate [72].

The above variation in the tannase structure can be attributed to the presence of various isoforms of the enzyme, or it may be also due to the presence of signal sequences which are required to transport the enzyme molecule from the cytosolic part of cell to the outside $[4,39]$.

Despite the structural differences between the tannases known, there are some physicochemical properties that remain more or less similar, as shown in Table 2. Most of tannases have been reported to have optimal temperature of activity between 30 and $40^{\circ} \mathrm{C}$ [3]. However, there are some information on the characterization of psychrophilic or thermophilic tannases; for example, Ramírez-Coronel et al. [42] and Battestin et al. [35] reported the production of thermo-stable tannases by Aspergillus niger and Paecilomyces variotii in SSF; these enzymes have their optimal activity at $70^{\circ} \mathrm{C}$. On the other hand, Kasieczka-Burnecka et al. [12] purified and characterized two psychrophilic tannases from an Antarctic strain of Verticillium sp., with an optimal temperature of 20 and $25^{\circ} \mathrm{C}$, respectively.

In the case of optimum $\mathrm{pH}$, most of the studied tannases showed their maximum activity at acid $\mathrm{pH}$ values (4.3-6.5), with isoelectric point ranged from 4.3 to 5.1 in most of the cases and are found to be stable in a wide range of $\mathrm{pHs}(2.0$ $8.0)[24,59,73,77-79]$. Recently, it has been reported that several tannases are highly active in extreme conditions of pH. Beena et al. [37] characterized an acidophilic tannase with optimal activity at $\mathrm{pH} 2.0$; also the enzyme retained around $80 \%$ of its maximal activity at $\mathrm{pH} 1.0$. On the other hand, the tannase of Lactobacillus plantarum ATCC 14917 has an optimal $\mathrm{pH}$ of 8.0 and retains about $88 \%$ its maximal activity at $\mathrm{pH} 9.0[40]$.

It has been reported that the $K_{M}$ value of tannase for different fungi with tannic acid was different. The $K_{M}$ values were $0.28,0.95,1.05,0.048$, and 0.00061 for tannase of $A$. niger, Cryphonectria parasitica, Verticillium sp., Penicillium chrysogenum, and Paecilomyces variotii, respectively $[12,79$ 81].

3.4. Tannase Gene. Hatamoto et al. [43] first reported the complete sequence of a tannase gene. They found the absence of introns in Aspergillus oryzae tannase gene and that it coded for a sequence of 588 aminoacids with a molecular weight of about $64000 \mathrm{kDa}$. Analysis of native protein indicated that the tannase gene product is translated as a single polypeptide that is cleaved by posttranslational modification into two tannase subunits linked by a disulfide bond. They concluded that mature protein consisted of four pairs of the two subunits, forming a hetero-octamer with a molecular weight of about 300000 . Since then, the tannase gene of a number of organisms has been identified by structural homology, but only a few have been confirmed at protein level.

Recently, León-Galván and coworkers [38] cloned and sequenced the complete CDNA of a tannase gene from Aspergillus niger. The open reading frame (ORF) was found to 


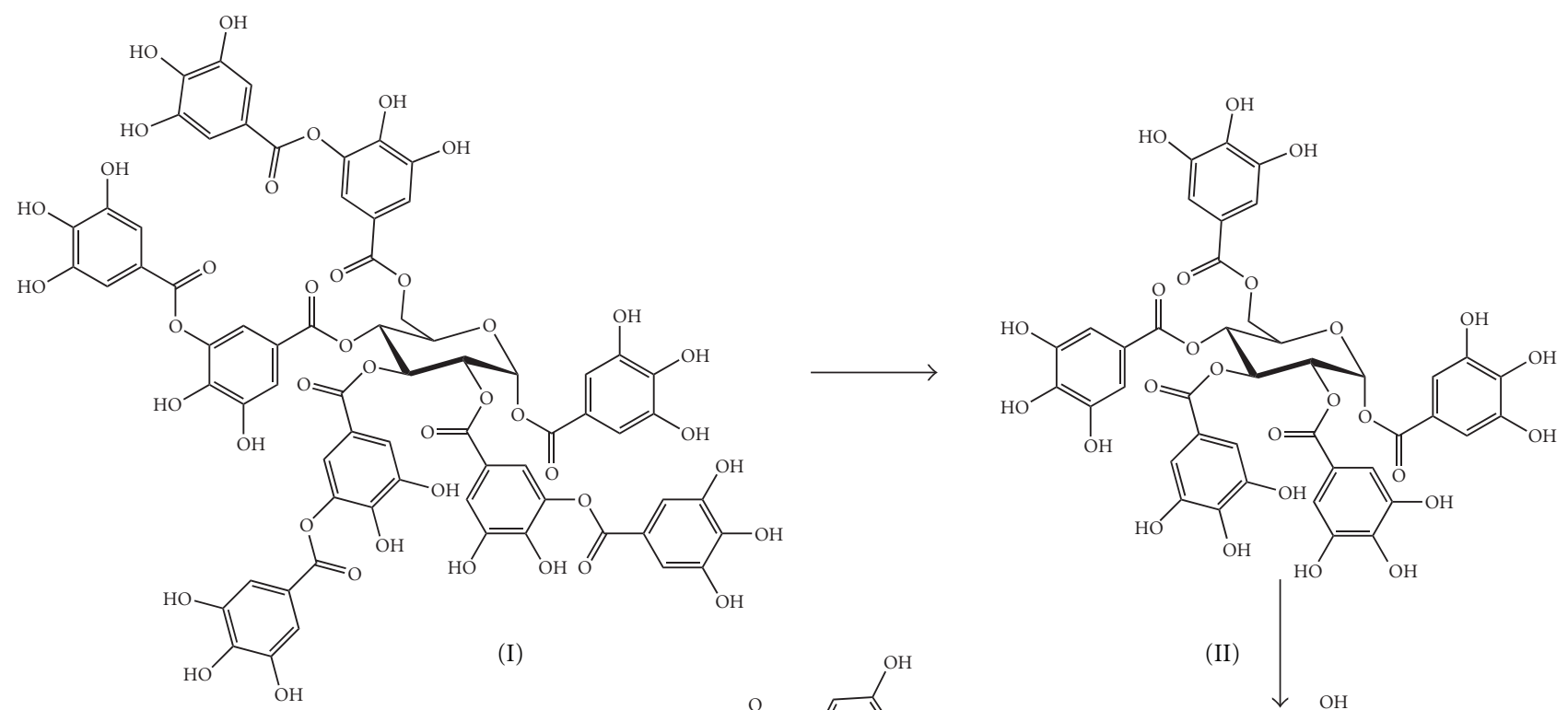<smiles>O=C(O)c1cc(O)c(O)c(O)c1</smiles><smiles>O=C(O)c1cc(O)c(O)c(O)c1</smiles>

(VI)
(V)

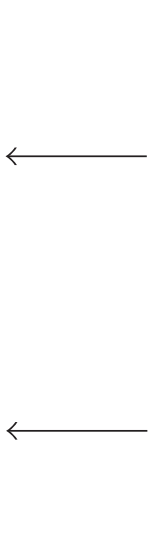

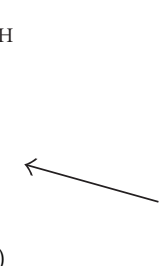

(IVa)

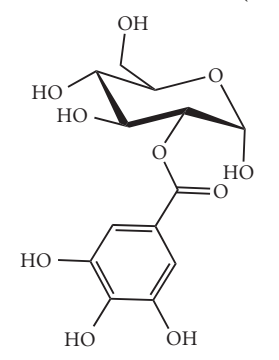

(IVb)

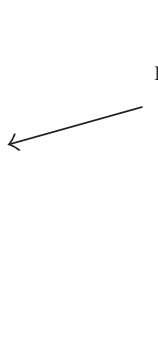<smiles>O=C(OCC1C(O)OC2C(OC(=O)c3cc(O)c(O)c(O)c3)C(OC(=O)c3cc(O)c(O)c(O)c3)C1C2OC(=O)c1cc(O)c(O)c(O)c1)c1cc(O)c(O)c(O)c1</smiles>

HO

(III)

FIgURE 1: Tannic acid hydrolysis pathway as proposed by Iibuchi et al. [60].

be of $1833 \mathrm{bp}$. The $5^{\prime}$ untranslated (UTR) region consisted of $1822 \mathrm{bp}$ and a 3' UTR of $1015 \mathrm{bp}$; both regions are substantially larger than the previously reported for the tannase gene of A. oryzae. Homology analysis of tannase ORF displayed a $75 \%$ identity with A. oryzae. Beena et al. [37] isolated and sequenced the tannase gene from a marine A. awamori strain and found an ORF of 1,122 bp. Homology studies revealed a higher similarity of the A. awamori gene with A. niger gene ( $82 \%$ identity) than with the A. oryzae gene $(77 \%)$. Böer et al. [21] identified the tannase-encoding gene from the dimorphic yeast Arxula adeninivorans. The gene has an ORF of $1764 \mathrm{bp}$ and encodes a 587 -amino acid protein, preceded by an $\mathrm{N}$-terminal secretion sequence comprising 28 residues. The deduced amino acid sequence was similar to those of tannases from A. oryzae (50\% identity) and A. niger (48\%).

On the other hand, Noguchi et al. [36] first reported a tannase gene from bacteria. They cloned and sequenced a novel gene $(\tan A)$ from Staphylococcus lugdunensis that encodes a polypeptide of 613 amino acids with tannase activity. The $\tan A$ gene was found to be specific for $S$. lugdunensis and has no significant similarity with genes of fungal tannases [82]. Later, Iwamoto and coworkers cloned and sequenced the tannase gene from Lactobacillus plantarum $(\tan L p l)$. The tanLpl gene was almost identical to a nucleotide sequence of $L$. plantarum WCFS1 designated as lp2956 (99.6\% identity), encoding a hypothetical protein but with a single base substitution at four positions and was similar (46.7\%) to tanA from S. lugdunensis [40]. More recently, Sharma and John [39] reported the characterization of the tannase gene from Enterobacter sp. Multiple alignment showed that Enterobacter sp. Tannase is not very much similar to tannase of $S$. lugdunensis and L. plantarum, since only $10 \%$ and $13 \%$ amino acid residues of Enterobacter sp. tannase are similar to those of S. lugdunensis and L. plantarum tannases, respectively. Additionally, bacterial tannase genes are not closely related to fungal tannases, as shown in Figure 4. 
<smiles>COC(=O)c1cc(O)c(O)c(O)c1</smiles>

Methyl gallate $\quad=\quad$ Gallic acid + Methanol

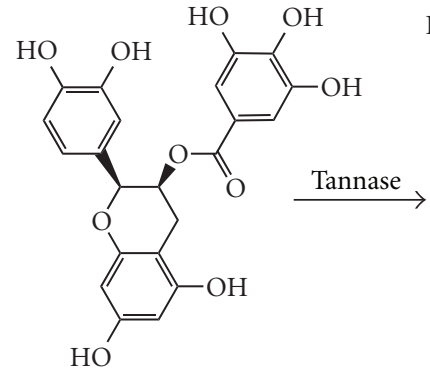

Epicatechin gallate

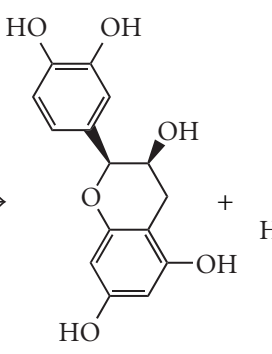<smiles>O=C(O)c1cc(O)c(O)c(O)c1</smiles>

Epicatechin $\quad+$

Gallic acid<smiles>O=C(O)c1cc(O)c(O)c(OC(=O)c2cc(O)c(O)c(O)c2)c1</smiles><smiles>C[14CH2][14CH2][C@H]1Oc2cc(O)cc(O)c2C[C@H](O)[C@H]1c1cc(O)c(O)c(O)c1</smiles>

Digallic acid $=$

2 Gallic acids

Epigallocatechin gallate

$=$

Epigallocatechin $\quad+$

Gallic acid

FIGURE 2: Several hydrolytic reactions catalyzed by tannase.

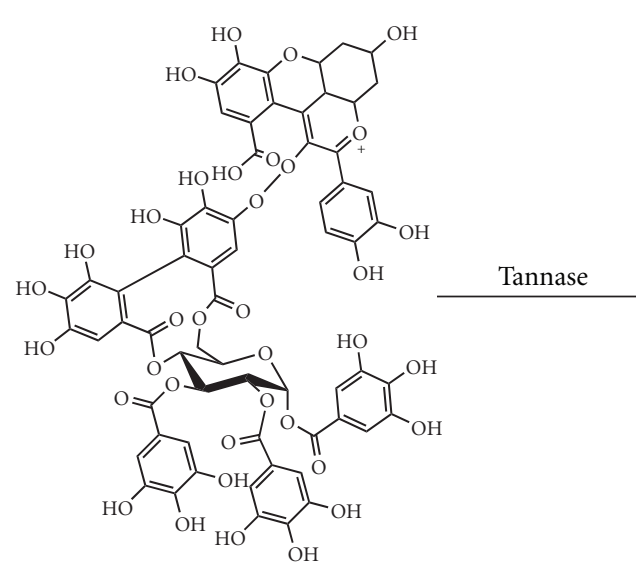

Rosacyanin A1

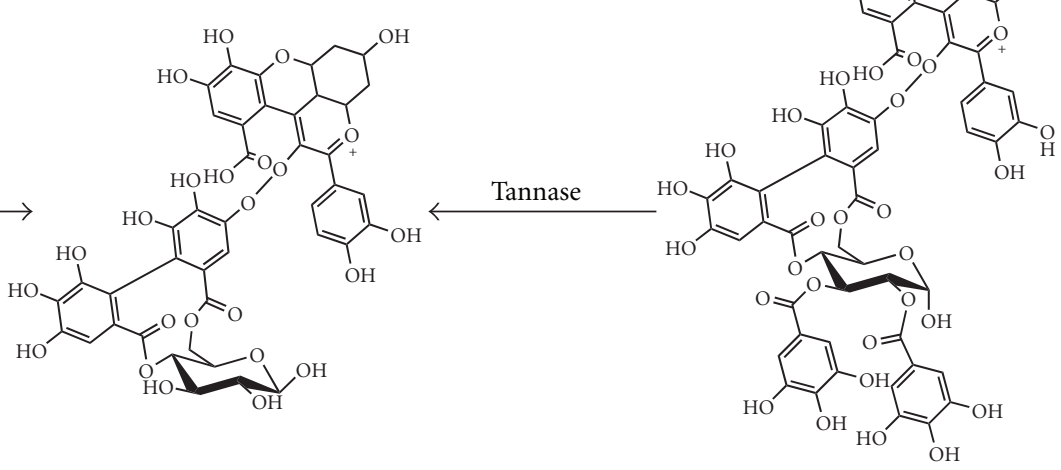

Degalloyalted rosacyanin
Rosacyanin A2

FIGURE 3: Selective hydrolysis of galloyl moieties of ellagitannins catalyzed by tannase.

\section{Applications of Tannin Acyl Hydrolase}

Tannase has several interesting applications in food, feed, chemical, and pharmaceutical industries. At the moment, the principal uses of tannase are in the elaboration of instantaneous tea and the production of gallic acid ester by depolymerization of tannin-rich materials [52]. But, due its hydrolytic and synthetic properties, tannase has several other potential applications. Several patents on these uses of tannases are showed in Table 3.
4.1. Instantaneous Tea Elaboration. After water, tea is the second most highly consumed beverage worldwide [83]. It is an infusion obtained from leaves of Camellia sinensis and is consumed by two-thirds of the world's population [84]. Tea drinking is associated with the reduction of serum cholesterol, prevention of low-density lipoprotein oxidation, and decreased risk of cardiovascular disease and cancer [85].

During the production of tea beverages, hot and clear tea infusions tends to form turbid precipitates after cooling. These precipitates, called tea cream, are formed by a complex 
TABLE 1: Structural properties of some characterized tannases.

\begin{tabular}{|c|c|c|c|c|c|}
\hline Microorganism & Culture system & MW (kDa) & Subunits & Glycosylation (\%) & Reference \\
\hline Arxula adeninivorans & SmF & 320 & $4 \times 80$ & 31.2 & {$[21]$} \\
\hline Aspergillus awamori & $\mathrm{SmF}$ & 230 & $6 \times 37.8$ & 8.0 & {$[37]$} \\
\hline Aspergillus niger & SSF & 225 & $50+75+100$ & n.d. & {$[31]$} \\
\hline Aspergillus oryzae & $\mathrm{SmF}$ & 310 & $4 \times(30+33)$ & 22.7 & {$[43]$} \\
\hline Candida sp. & $\mathrm{SmF}$ & 250 & $2 \times 120$ & 64 & {$[67]$} \\
\hline Enterobacter sp. & SmF & 90 & $1 \times 90$ & 0 & [39] \\
\hline Lactobacillus plantarum & $\mathrm{SmF}$ & 50 & $1 \times 50$ & 0 & {$[40]$} \\
\hline \multirow{2}{*}{ Quercus robur } & Plant & 150 & $2 \times 75$ & n.d. & {$[56]$} \\
\hline & leaves & 300 & $4 \times 75$ & & \\
\hline Selenomonas ruminantium & $\mathrm{SmF}$ & 59 & $1 \times 59$ & 0 & {$[68]$} \\
\hline
\end{tabular}

TABle 2: Physicochemical properties of some characterized tannases.

\begin{tabular}{|c|c|c|c|c|c|c|c|c|c|}
\hline Microorganism & Substrate & $\begin{array}{c}\text { Temperature } \\
\text { optimum } \\
\left({ }^{\circ} \mathrm{C}\right)\end{array}$ & $\begin{array}{c}\text { Stability } \\
\text { temperature } \\
\left({ }^{\circ} \mathrm{C}\right)\end{array}$ & pH optimum & Stability $\mathrm{pH}$ & $\mathrm{pI}$ & $K_{M}(\mathrm{mM})$ & $\begin{array}{c}V_{\mathrm{Max}} \\
(\mu \mathrm{mol} / \mathrm{min} \cdot \mathrm{mg})\end{array}$ & Reference \\
\hline $\begin{array}{l}\text { Arxula } \\
\text { adeninivorans }\end{array}$ & $\begin{array}{l}\text { Methyl } \\
\text { gallate }\end{array}$ & 40 & $\leq 50$ & 6.0 & $5.0-7.0$ & n.d. & 4.4 & n.d. & {$[21]$} \\
\hline $\begin{array}{l}\text { Aspergillus } \\
\text { awamori }\end{array}$ & $\begin{array}{l}\text { Methyl } \\
\text { gallate }\end{array}$ & 30 & $\leq 30$ & $2.0,8.0$ & 2.0 & 4.4 & 1.9 & 830 & {$[37]$} \\
\hline Aspergillus flavus & Tannic acid & $50-60$ & $\leq 60$ & $5-5.5$ & $5.0-5.5$ & n.d. & 0.05 & n.d. & {$[71,73]$} \\
\hline Aspergillus niger & $\begin{array}{l}\text { Methyl } \\
\text { gallate }\end{array}$ & 30 & $\leq 60$ & $5.0-6.5$ & $4.5-6.5$ & n.d. & 0.6 & 5 & {$[74]$} \\
\hline $\begin{array}{l}\text { Aspergillus niger } \\
\mathrm{Aa} 20\end{array}$ & Tannic acid & $60-70$ & $\leq 90$ & 6.0 & $3.5-7.0$ & 3.8 & n.d. & n.d. & {$[42]$} \\
\hline $\begin{array}{l}\text { Aspergillus niger } \\
\text { ATCC } 16620\end{array}$ & $\begin{array}{l}\text { Methyl } \\
\text { gallate }\end{array}$ & $30-40$ & $\leq 65$ & 6.0 & $4.0-8.0$ & n.d. & 103 & 4.25 & {$[75]$} \\
\hline $\begin{array}{l}\text { Aspergillus niger } \\
\mathrm{GH} 1\end{array}$ & $\begin{array}{l}\text { Methyl } \\
\text { gallate }\end{array}$ & 60 & $\leq 50$ & 6.0 & $4.0-6.0$ & 3.5 & 0.041 & 11.03 & {$[31]$} \\
\hline $\begin{array}{l}\text { Aspergillus niger } \\
\text { LCF8 }\end{array}$ & Tannic acid & 35 & $\leq 45$ & 6.0 & $3.5-8.0$ & 4.3 & n.d. & n.d. & {$[59]$} \\
\hline $\begin{array}{l}\text { Aspergillus niger } \\
\text { van Tieghem }\end{array}$ & $\begin{array}{l}\text { Methyl } \\
\text { gallate }\end{array}$ & 60 & $\leq 60$ & 6 & $4.5-7.5$ & n.d. & 0.2 & 5 & {$[76]$} \\
\hline Aspergillus oryzae & Tannic acid & 40 & $\leq 45$ & 5.5 & $4.5-6.0$ & n.d. & 7.35 & 83 & {$[77]$} \\
\hline Candida sp. & Tannic acid & 50 & $\leq 70$ & 6.0 & $3.5-7.5$ & n.d. & n.d. & n.d. & {$[78]$} \\
\hline $\begin{array}{l}\text { Lactobacillus } \\
\text { plantarum }\end{array}$ & $\begin{array}{l}\text { Methyl } \\
\text { gallate }\end{array}$ & 40 & $\leq 45$ & 8.0 & $7.5-9.0$ & n.d. & 0.62 & n.d. & {$[40]$} \\
\hline $\begin{array}{l}\text { Paecilomyces } \\
\text { variotii }\end{array}$ & Tannic acid & 55 & $\leq 55$ & 5.5 & $4.5-6.5$ & n.d. & $6.1 \times 10^{-4}$ & 5.6 & {$[34]$} \\
\hline Penicillium variable & Tannic acid & 50 & $\leq 80$ & 5.0 & $3.0-8.0$ & n.d. & 32 & 1.11 & {$[32]$} \\
\hline $\begin{array}{l}\text { Verticillium sp. } \\
\text { (TAH 1) }\end{array}$ & Tannic acid & 25 & $\leq 30$ & 5.5 & $4.5-6.0$ & 5.8 & 1.05 & n.d. & {$[12]$} \\
\hline $\begin{array}{l}\text { Verticillium sp. } \\
\text { (TAH 2) }\end{array}$ & Tannic acid & 20 & $\leq 30$ & 5.5 & $5.0-7.5$ & 6.2 & 1.05 & n.d. & {$[12]$} \\
\hline
\end{tabular}

n.d.: Not determined.

mixture of polyphenols. Tea cream formation is a quality problem and may have antinutritional effects [86]. Tannase can hydrolyze the ester bonds of catechins to release free gallic acid and water-soluble compounds with lower molecular weight, reducing turbidity and increasing solubility of tea beverage in cold water. Thus, tannase has been widely used to hydrolyze tea cream in the processing of tea [87].
Enzymatic treatment of tea beverage leads to a better color appearance, less cream formation, better taste, mouth feeling, and overall acceptance [86]. Also, the hydrolysis of the main tea phenols epigallocatechin gallate and epicatechin gallate to epigallocatechin and epicatechin, respectively, increases the antioxidant activity of tea beverage [88]. 


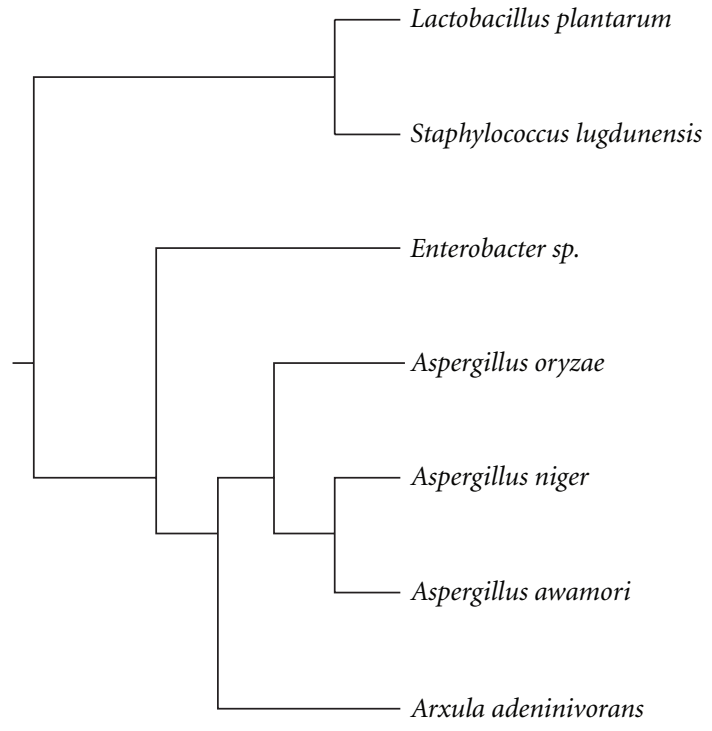

Figure 4: Phylogenetic tree showing the relationship between the reported sequences of the tannase-encoding gene.

4.2. Beverage Clarification. New fruit juices (pomegranate, cranberry, raspberry, etc.) have recently been acclaimed for their health benefits, in particular, for their antioxidant properties. However, the presence of high tannin content in those fruits is responsible for haze and sediment formation, as well as for color, bitterness, and astringency of the juice upon storage. Enzymatic treatment with tannase may be used to improve the quality of these juices [3].

Rout and Banerjee [89] reported the use of tannase for pomegranate juice debittering. Enzymatic treatment resulted in 25\% degradation of tannin, while a combination of tannase and gelatin (1:1) resulted in $49 \%$ of tannin degradation. This treatment has no negative impact on the biochemical and quality attributes of the fruit juice. Hydrolysis by immobilized tannase removed up to $73.6 \%$ of the tannin present in Indian gooseberry (Phyllanthus emblica) juice. This enzymatic treatment reduced the content of tannin but increased the gallic acid concentration with a minimum reduction in vitamin C (only $2 \%$ ) [90, 91].

Tannase is used as clarifying agent in refreshing drinks with coffee flavor [50], and, recently, a process for the enhancement of the antioxidant properties of coffee by tannase and other enzymes has been patented [92].

Tannase has also been utilized in grape musts and barley worts as a prefermentative treatment, coupled with conventional fining for stabilizing wine and beer [93]. Tannase is employed for the elaboration of acorn wine. Its use in this process favors the production of a better beverage with an alcoholic content of $10 \%$, reducing sugars content of $7 \%$ and a $\mathrm{pH}$ of 4.0 . In this process, tannase produced by an Aspergillus strain helps improving the flavor of the beverage $[4]$.

4.3. Gallic Acid Production. Gallic acid (3,4,5-trihydroxybenzoic acid) is a phenolic compound and the monomeric unit of the gallotannins and complex tannins. Gallic acid and related compounds possess many potential therapeutic properties including anticancer and antimicrobial properties [94]. Its major application area is in the manufacture of the antibacterial agent trimethoprim. It is also used in leather industry, in manufacturing gallic acid esters, such as propyl gallate, a potent antioxidant utilized as antioxidant in fats and oils, in the manufacture of pyrogallol and as a photosensitive resin in semiconductor production [10].

Conventionally, gallic acid is produced by acid hydrolysis of tannins, but this process releases a large amount of toxic effluent that causes environmental hazards [95]. Thus, biotechnological production of gallic acid by tannin fermentation or enzymatic hydrolysis should be preferred. However, these biological methods should be optimized to offer highly productive bioprocesses [96].

Several fungi, bacteria, and yeasts have been used to produce gallic acid from tannin-rich materials with the simultaneous production of tannase. Microbial production of gallic acid from tara (Caesalpinia spinosa) [97], sumac (Rhus coriaria) [98], myrobalan (Terminalia chebula) [99], teri pods (Caesalpinia digyna) [100], creosote bush (Larrea tridentata), and tar bush (Flourensia cernua) [101], among others, has been published. The main difficulty in the development of a successful bioconversion process is the sensitivity of the microorganisms to tannin and the oxidation of the unused tannin [102]. Additionally, gallic acid, released from tannin, can be easily assimilated by microorganisms. However, several strategies such as coculture, strain improvement and optimization of culture conditions have led to the development of fermentation processes with yields higher than $90 \%$ of theoretical value $[13,99,103]$.

On the other hand, there are only a few papers on the enzymatic production of gallic acid. Battestin and coworkers [104] described the simultaneous production of gallic acid and EGC from an extract of green tea by free Paecilomyces variotii tannase. More recently, Curiel et al. [27] reported a process for the enzymatic production of gallic acid. They immobilized a recombinant tannase from L. plantarum expressed in Escherichia coli then utilized the immobilized enzyme for the hydrolysis of commercial tannic acid. At least $95 \%$ of tannic acid was transformed into gallic acid, obtaining an almost pure compound.

4.4. Synthesis of Gallic Acid Esters. Tannase, is an enzyme characterized for catalyzing the hydrolysis of gallic acid esters. But, under appropriate conditions, this enzyme can synthesize esters of gallic acid. Toth and Hensler discovered the ability of soluble tannase to produce gallic acid esters. Weetall [105] reported the enzymatic synthesis of a variety of gallic acid esters. He applied an immobilized tannase from Aspergillus niger to a solution of gallic acid in different alcohols $\left(\mathrm{C}_{1}-\mathrm{C}_{12}\right)$ and diols $\left(\mathrm{C}_{3}-\mathrm{C}_{6}\right)$. Tannase was capable of catalyze the synthesis of esters and diesters of gallic acid, and maximum esterification efficiency was found with alcohol an diol with 4-5 carbon chain. Raab et al. [106] utilized an $A$. oryzae tannase immobilized in Eupergit $\mathrm{C}$ for the galloylation of catechins in room temperature ionic liquids 
TABLE 3: Selected patents on tannase application published during the last 10 years.

\begin{tabular}{|c|c|c|c|}
\hline Year & Assignee & Title & Patent no. \\
\hline 2001 & Quest International Nederland & Process for the production of beer having improved flavour stability. & EP 1122303 \\
\hline 2002 & Unicafe Inc. & $\begin{array}{l}\text { Tea extracts stabilized for long-term preservation and method of producing } \\
\text { same. }\end{array}$ & USP $6,365,219$ \\
\hline 2002 & $\begin{array}{l}\text { Purdue Research Foundation } \\
\text { Pharmanex, Inc. }\end{array}$ & Tea catechin formulations and processes for making same. & USP $6,428,818$ \\
\hline 2004 & University of South Florida & Vasodilating compound and method of use. & USP $6,706,756$ \\
\hline 2004 & Purdue Research Foundation & $\begin{array}{l}\text { Compositions based on vanilloid-catechin synergies for prevention and } \\
\text { treatment of cancer. }\end{array}$ & USP $6,759,064$ \\
\hline 2004 & $\begin{array}{l}\text { Lipton, division of Conopco, } \\
\text { Inc. }\end{array}$ & Cold brew tea. & USP $6,780,454$ \\
\hline 2004 & Kyowa Hakko Kogyo Co., Ltd. & Process for purification of proanthocyanidin oligomer. & USP $6,800,433$ \\
\hline 2004 & $\begin{array}{l}\text { Lipton, division of Conopco, } \\
\text { Inc. }\end{array}$ & Cold water infusing leaf tea. & USP $6,833,144$ \\
\hline 2006 & Nestec S A & Soluble coffee product. & EP 1726213 \\
\hline 2006 & Eisai Co., Ltd. & Diagnostic agent and test method for colon cancer using tannase as index. & USP 7,090,997 \\
\hline 2006 & Unilever Bestfoods & Black tea manufacture. & USP $7,108,877$ \\
\hline 2007 & Eisai R\&D Man Co. Ltd. & Novel tannase gene and protein thereof. & EP 1837400 \\
\hline 2008 & Probelte Pharma S A & Process for preparing pomegranate extracts. & EP 1967079 \\
\hline 2008 & Novozymes, Inc. & Methods for degrading lignocellulosic materials. & USP $7,354,743$ \\
\hline 2008 & $\begin{array}{l}\text { The Procter \& Gamble } \\
\text { Company }\end{array}$ & $\begin{array}{l}\text { Foam-generating kit containing a foam-generating dispenser and } \\
\text { a composition containing a high level of surfactant. }\end{array}$ & USP $7,402,554$ \\
\hline 2008 & Novozymes, Inc. & Methods for degrading or converting plant cell wall polysaccharides. & USP $7,413,882$ \\
\hline 2009 & Kirin Brewery & Method of enzymatically treating green tea leaves. & EP 2036440 \\
\hline 2009 & Kao Corp. & Beverage packed in foam container. & EP 2036446 \\
\hline 2009 & Kao Corp. & Green tea drink packed in container. & EP 2098121 \\
\hline 2009 & Colgate-Palmolive Co. & Antiplaque oral composition containing enzymes and cyclodextrins. & USP $7,601,338$ \\
\hline 2009 & Novozymes, Inc. & Methods for enhancing the degradation or conversion of cellulosic material. & USP $7,608,689$ \\
\hline 2010 & Kao Corp. & Process for producing purified tea extract. & EP 2225952 \\
\hline 2010 & University of California & $\begin{array}{l}\text { Method for lowering blood pressure in prehypertensive individuals and/or } \\
\text { individuals with metabolic syndrome. }\end{array}$ & USP 7,651,707 \\
\hline 2010 & J.M. Huber Corporation & High-cleaning silica materials and dentifrice containing such ones. & USP $7,670,593$ \\
\hline 2010 & Novozymes, Inc. & $\begin{array}{l}\text { Polypeptides having cellulolytic enhancing activity and nucleic acids encod- } \\
\text { ing the same. }\end{array}$ & USP $7,741,466$ \\
\hline 2010 & Constellation Brands, Inc. & Grape extract, dietary supplement thereof, and processes therefore. & USP $7,767,235$ \\
\hline 2011 & Taiyo Kagaku Co., Ltd & Composition for inhibiting thrombosis. & USP $7,914,830$ \\
\hline 2011 & Danisco US Inc. & Polyol oxidases. & USP $7,919,295$ \\
\hline
\end{tabular}

(RTIL). RTIL are generally composed of organic cations and inorganic anions and are characterized by not being crystallized at room temperature. The biocatalyzed reactions in ionic liquids have higher selectivity, faster rates, and increased enzyme's thermal stability.

Mycelium-bound tannase from Aspergillus niger has been employed to catalyze the synthesis of propyl gallate in organic solvents. After evaluating the reaction parameters, a maximum molar conversion of $65 \%$ was achieved. These results were more promising than those of immobilized pure tannase $(49.4 \%$ yield) or microencapsulated mycelium-bound tannase $(36.2 \%$ yield) previously reported by the same research group $[107,108]$. Since under optimum fermentation conditions tannase is strongly bound to the mycelium
[109], the use of whole cells as biocatalyst could offer several technical and economical advantages such as the avoidance of costly and time-consuming purifications [108].

Another interesting approach is the direct synthesis of propyl gallate by direct transesterification of tannic acid. Sharma and Gupta [110] immobilized an Aspergillus niger tannase on Celite and applied it to a solution of commercial tannic acid in n-propanol. After optimizing the process parameters, they obtained a reasonable product yield of about $86 \%$.

4.5. Elucidation of Polyphenolic Compounds Structure. Tannase has been widely utilized in research and fine chemistry for the elucidation of polyphenolic compounds structure. 
For example, Armitage et al. [111] studied the structure of Chinese, Turkish, Sumac, and Tara tannins. They found, after hydrolysis by tannase, that such tannins have a core of glucose and suggested that contains 8-9 galloyl moieties per tannin molecule.

More recently, ellagitannins and complex tannins have attracted the attention of many researchers because of their diverse biological activities and their potential as therapeutic agents. Since tannase selectively hydrolyzes the galloyl residues present in these tannins, it has played an important role in the elucidation of complex polyphenolic compounds. Tanaka et al. [112] reexaminated the structure of cercidinin A, an ellagitannin isolated from the bark of Cercidiphyllum japonicum. They utilized a commercial tannase for selectively hydrolyzing the galloyl groups of molecule and deduced the location of the esters on the glucopyranose by twodimensional NMR spectral analysis. Ivanov and coworkers [113] isolated two catechins from an aqueous ethanol extract of Bergenia crassifolia rhizomes $[(+)$-catechin 3,5-di$\mathrm{O}$-gallate and $(+)$-catechin 3-O-gallate]. These compounds strongly inhibited human pancreatic lipase and exhibited a remarkable free radical-scavenging ability. The structure of these molecules was elucidated using MS NMR before and after degalloylation by tannase.

4.6. Animal Feed Preparation. It is well known that high levels of dietary tannins have negative effects on animal nutrition; these effects are related to their capacity to bind macromolecules. Tannins form strong complex with enzymes, minerals, and other nutrients. They are also responsible of a bitter taste, which considerably reduces the feed intake [50].

Tannins are ubiquitous in nature and are widely found in feedstuffs, forages, fodders, and agroindustrial wastes, affecting livestock production [114]. Antinutritional effect of tannin could be reduced by a treatment with tannase or tannaseproducing microorganism. For example, there are some cultivars of sorghum with high content of tannins. Tannin content could be decreased by an enzymatic treatment, and this material could be used as complement in animal diet [4].

Nuero and Reyes [115] reported the production of an enzymatic extract containing tannase from mycelial wastes of penicillin manufacture. This preparation was applied to several flours used as animal feed (barley, bran, maize, oat, rye, soya, and wheat flour). The enzymatic extract from mycelia waste released similar amounts of reducing sugars from all flours when compared with a commercial enzymatic additive used in animal feeding. These observations indicated that tannase-containing preparation has a high potential as supplements for animal feeding.

4.7. Nutritional Improvement of Legume Flours. Legumes are of major nutritional importance, especially in developing countries. Seed legumes have high protein contents, and this protein is of good biological value. However, they also have several antinutritional factors, affecting the digestibility of nutrients [116]. Different thermal and biological processes have been used to reduce the antinutritional factors content, increasing their nutritional value. The flours obtained from the processed legumes can be used as ingredients in food preparations.

Several researchers have proposed the use of tannase alone or in combination with other enzymes for the degradation of some antinutritional factors (tannins) present in legume flours. Dueñas et al. [117] studied the effect of the addition of tannase and other enzymes to a lentils (Lens culinaris) flour. They found the production of several phenolic compounds (gallic acid, gallic aldehyde, protocatechuic acid, and quercetin 3-O-rutinoside, among others) after the treatment with tannase, the decrease of other phenolics such as catechin, epicatechin, and catechin 3-O-glucose, and significant increment on the antioxidant activity. However, further investigations, from the same research group, demonstrated that these biochemical changes cannot be completely attributed to the action of tannase. But during enzymatic hydrolysis with tannase, endogenous enzymes were activated. These enzymes can bring out synergic and/or antagonist effects depending on the structure of phenolic compound [118].

On the other hand, the application of tannase on pea (Pisum sativum) led to a decrease on all the phenolic compounds studied and a reduction of the antioxidant capacity [119]. But, in a different experiment, the hydrolysis of pea flour by tannase led to a significant improvement in daily weight gain of rats. This increment was associated with a higher dietary intake of food and total available sugars [120].

\subsection{Bioremediation of Tannin-Contaminated Wastewaters.} Tannins occur commonly in the effluents derived from several agroindustries. The treatment of this kind of wastewaters is usually difficult because tannins are highly soluble and inhibit the growth of many microorganisms [121]. Tannase can be potentially used for the degradation of tannins in those effluents [50].

Several authors have reported the biodegradation of tannin-containing wastewaters using model systems. Kachouri and coworkers [122] studied the biodegradation and decolourisation of olive-mill wastewater by Aspergillus flavus. The microorganism removed $58 \%$ of color and $46 \%$ of the chemical demand of oxygen of the wastewater after 6 days of cultivation. Authors associated this degradation with deconcomitant production of tannase, since no lignin peroxidase nor manganese peroxidase were detected, and laccase activity was much lower than tannase activity.

More recently, Murugan and Al-Sohaibani [123] reported the use of immobilized tannase from Aspergillus candidus for the removal of tannin and the associated color from a tannery effluent. Enzymatic treatment removed about $42 \%$ of the tannin content and $20 \%$ of the color of tannery wastewater. These findings suggest than tannase or tannaseproducing microorganism could be utilized for a pretreatment of tannin-rich wastewaters. However, more research is needed to implement this biological treatment at large scale.

4.9. Other Potential Applications of Tannase. Fuel ethanol production from agroindustrial wastes has gained much attention in recent years. When these feed stocks are pretreated 
for delignification, simple or oligomeric phenolics and derivatives are generated from lignin. These compounds can inhibit the hydrolysis catalyzed by cellulases. Tannase could be utilized for degradation of these oligomeric phenolics and, by doing so, mitigate the inhibition on cellulolysis [124].

Tannase gene and tannase activity could be utilized for the identification of Staphylococcus lugdunensis in humans and as an indicator of colon cancer [36]. Tannase has been utilized for the production of molecules with therapeutic applications, such as some esters derived from prunioside A with anti-inflammatory activity [125]. Other potential applications of tannase are found in the manufacture of laundry detergents as an additive, in cosmetology to eliminate the turbidity of plant extracts, and in the leather industry to homogenize tannin preparation for high-grade leather tannins $[52,126]$.

\section{Upstream Processing of Tannin Acyl Hydrolase}

Despite the many applications of tannase, industrial-scale production is very limited, mainly because of its high production cost. At our knowledge, only a few companies produce and sell tannase [50], and the cost of this enzyme is often much more expensive that other industrial-grade enzymes, even from the same supplier.

Therefore, many efforts have been made to improve the productions systems. These works include the screening for new tannase-producing microorganisms, the application of novel fermentation systems, the optimization of culture conditions, and the production of the enzyme by recombinant microorganism, among other strategies.

5.1. Tannase Sources. Tannase can be obtained from tanninrich plants and animal tissues, but, for its industrial production, microbial sources are preferred. Enzymes produced by microorganisms are usually more stable than their counterparts of plant or animal. In addition, the fermentation process can produce large amounts of enzymes in a constant and can be controlled more easily [52].

It is well known that tannins inhibit the growth of many microorganisms, but there are species that have developed mechanisms to degrade and use them as sole carbon source. These mechanisms include the production of tannase and other related enzymes [127]. It was previously stated that only a few microorganisms are able to produce tannase. However, it has been identified that more than 70 species produce this enzyme, and the number keeps growing as a result of the continuing search for new sources of this enzyme [128]. Tannase is mostly produced by fungi from the Aspergillus and Penicillium genus and lactic acid bacteria.

Several research groups have recently carried out a search for new sources of tannase. These researches are made for finding out microorganisms able to produce higher enzymatic titers or enzymes with desirable properties, such as more stability at a broad range of temperature and $\mathrm{pH}$.

The most common strategy is to isolate microorganisms from tannin-rich environments and investigate their ability to produce tannase. For example, Murugan et al. [129] isolated 10 morphological different fungal strains from a tannery effluent in India. They isolated the microorganism by serial dilution in PDA slants and investigated for tannase production by a simple plate assay. Selected microorganisms were tested for tannase production under SmF in a stirred tank bioreactor. Pepi and coworkers isolated 3 bacterial strains capable of degrading tannic acid from olive mill waste mixtures. The isolated bacteria, belonging to the Pantoea and Serratia genus, were able to grow in SmF with tannic acid as sole carbon source and completely degraded a 1\% tannin solution within $24 \mathrm{~h}$ [9].

Other common approach is to investigate the tannase presence in microorganisms obtained from culture collections. Pinto and coworkers investigated the tannase activity of 17 wild type and 13 mutant strains of Aspergillus niger from a local culture collection in Brazil (EMBRAPA/Food Technology stock collection). They selected the potential tannase producers by their ability to grow in agar plates with tannic acid as sole carbon source. Then the selected microorganisms were utilized for tannase-production under SSF [130]. A similar strategy was developed by the group of Battestin and Macedo [81]. They screened the tannase producing potential of five hundred fungal cultures from the Food Science Department, UNICAMP Culture Collection (Brazil) and identified the best tannase-producing fungus as Paecilomyces variotii.

On the other hand, a few researches have isolated microorganism from extreme environments to find extremophile tannases with particular characteristics desired. For example, Cruz-Hernández and coworkers [5] isolated and characterized eleven fungal strains from soil and tannin-rich plants of the Mexican semidesert. These xerophilic fungi were able to produce tannase and degrade high tannin amounts in lowhumidity conditions. Kasieczka-Burnecka et al. [12] isolated an Antarctic filamentous fungus from the soil of the King George Island (South Shetlands). This strain (identified as Verticillium sp.) produced two psychrophilic tannases with an optimal temperature of 20 and $25^{\circ} \mathrm{C}$, respectively.

5.2. Production System. Traditionally, industrial production of tannase was carried out exclusively in SmF systems. However, in the recent years a number of investigations have shown the benefits of SSF for production of this and other enzymes. These advantages are higher degrees of activity, increased productivity, extracellular nature of the enzyme, and increased stability to $\mathrm{pH}$ and temperature changes. In addition, the SSF allows the construction of more compact reactors with less energy requirements and causing less damage to the environment $[52,131]$.

Cruz-Hernández et al. [132] evaluated the effect of culture system on the production of tannase by an Aspergillus niger strain. They found that enzyme production was about four times higher in SSF compared with SmF. These results are similar to those previously obtained by Aguilar et al. $[28,29]$ with another strain of $A$. niger. They obtained an activity and productivity at least 2.5 times higher in SSF and associated the low productivity of the SmF to a possible degradation of the enzyme that is not present in SSF. 
Lekha and Lonsane [133] compared the production of tannase in SSF, SmF, and Liquid Surface Fermentation (LSF) by Aspergillus niger PKL104 and found that the enzyme production in SSF was about 2.5 and 4.8 times higher than that obtained by SmF and LSF, respectively. In addition, the activity peak reached in SSF was obtained in about half the time required by the other two systems. Results obtained by Rana and Bhat [74] with another A. niger strain also showed that the SSF system is better for tannase production; in that case, the maximum yield achieved in SSF was 1.6 times higher than that obtained by SmF; also tannase produced by SSF was more stable at a wide range of temperatures and $\mathrm{pHs}$.

SSF traditionally involves the microbial growth on a moistened natural solid substrate in the absence of freeflowing water. But, in the last years, a second type of SSF system is gaining acceptation. This second system involves the utilization of an inert solid support impregnated with a defined culture media [134]. This culture system facilitates the quantification of biomass, substrate, and products during fermentation and is particularly useful in basic studies on SSF.

Among the natural supports that have been used for the production of tannase are sugarcane bagasse [135], wheat bran [75], tamarind seed powder [136], palm kernel cake [136], cashew apple bagasse (Anacardium occidentale), fruits of Terminalia chebula [99], pod cover of Caesalpinia digyna [99], ber leaves (Ziziphus mauritiana) [137], jamun leaves (Syzygium cumini) [137], amla leaves (Phyllanthus emblica) [137], jawar leaves (Sorghum vulgaris) [137], and Creosote bush leaves (Larrea tridentata) [138]. The most commonly used inert support for the production of tannase is the polyurethane foam $[28,29]$.

There are several papers on the production of tannase in innovative systems. For example, Kar et al. [100] reported the simultaneous production of tannase and gallic acid by Rhizopus oryzae in a modified solid-state fermentation system (mSSF). The mSSF was carried out in a Growtek bioreactor and showed several advantages over traditional SSF, including increased production of tannase (1.7 times) and a gallic acid yield almost three times higher. Van de Lagemaat and Pyle $[14,139]$ developed a prototype of continuous solid-state fermentation (cSSF) for fungal tannase production; the bioreactor achieved a good mix that allowed their operation with a sterile food; however, the rotation resulted in reduced growth and sporulation.

Another interesting approach is the production of tannase by immobilized cells. The immobilization of cells offers many advantages over the utilization of free cells, such as immobilized cell particles are more easily to handle and can be packed in fermenter system for industrial processes; the support materials provide a stabilizing effect on the cellular activities; the enzymes secreted are largely free of cells and cell debris which facilitates downstream processing [140]. Das Mohapatra and coworkers immobilized active cells of Bacillus licheniformis in $\mathrm{Ca}$ alginate beads and used them for tannase production under semicontinuous fermentation. Tannase production by immobilized cells was about 1.70 fold higher than that obtained by free cells in the same incubation period. The immobilized cells were reutilized over 13 repeated cycles and reached a maximum level at the third cycle [141]. More recently, Darah et al. [140] reported the immobilization of Aspergillus niger cells by entrapment in scouring mesh cubes. The immobilization of cells led to a $41.6 \%$ increment in tannase production and allowed the reutilization of the cells.

5.3. Optimization of Culture Parameters. The tannase production remains a challenge for biotechnologists, due to its high processing cost. In the previous sections, it was mentioned that different research groups have devoted considerable efforts in finding new sources of tannase and designing better production systems. However, the conditions for obtaining the maximal production of the enzyme depend on two factors: the system utilized and the source of the enzyme. Thus, recently there have been published a number of papers dealing with the optimization of solid-state fermentation systems for the production of tannase [16-18, 142-145]. In most of those cases, optimization was carried out by changing one independent variable at a time while fixing all the others at a certain level. This method is very time consuming and requires a large number of experiments to determine the optimum levels. Also, this approach does not include the interactive effects among the variables and is, therefore, unreliable. Thus, an statistical optimization is preferred [146].

Raaman et al. optimized the extracellular tannase production by Paecilomyces variotii in SSF changing one factor at time and obtained an increase of 1.23-fold in enzyme production. Das Mohapatra and coworkers reported the optimization of tannase production by Bacillus licheniformis in SmF using Taguchi's methodology. They reached a 2.18-fold increment in tannase [19].

Sharma and coworkers [147] optimized tannase production by Aspergillus niger using response surface methodology and obtained 2.01-fold improvement on enzyme production. Naidu et al. [148] optimized the tannase production by Aspergillus foetidus in SmF utilizing subsequently two statistical methods: first, a Plackett-Burman design was employed for find out the key factors for tannase production, then these factors were optimized by response surface methodology using a central composite design. With this strategy, they obtained a twofold increase in tannase activity in comparison to the medium optimized by the conventional one factor at a time method. In addition, the number of nutrients for the production of tannase was reduced from ten to four after optimization.

5.4. Recombinant Tannases. Because of the many technical difficulties involved in production of tannase using traditional technologies; in recent years, there has been a great interest for the production of this enzyme by recombinant microorganisms. In 1996, Hatamoto et al. cloned and sequenced for the first time the gene encoding tannase from Aspergillus oryzae. This gene was further expressed in a tannase low-producing A. oryzae strain. Tannase production in transformants was at least threefold higher than that in the wild strain. Southern blotting confirmed that the increase in the tannase level was due to the presence of additional 
copies of the tannase gene in the genome of the transformants [43]. Based on these results, Albertse sequenced the tannase gene from four tannase-producing Aspergillus species. He cloned and inserted the tannase gene from $A$. oryzae in Saccharomyces cerevisiae. However, the biological activity of the recombinant tannase was expressed at very low level, probably due to differences in posttranslational modifications in the heterologous system with respect to the wild microorganism [24].

Zhong and coworkers successfully cloned and sequenced a tannase gene from Aspergillus oryzae in the methylotrophic yeast Pichia pastoris. The inserted gene was under the control of $A O X 1$ promoter and inframe with $\alpha$-factor signal sequence. Large amounts of extracellular tannase (7000 U/L) were obtained with transformed yeast in fedbatch SmF system, using glycerol as carbon source and methanol as tannase inducer [23]. Yu and coworkers achieved efficient intracellular expression of $A$. oryzae tannase in $P$. pastoris under the control of the $A O X 1$ promoter. The recombinant $P$. pastoris were used to synthesize propyl gallate in organic solvent, and the yield of propyl gallate was $53 \%$.

More recently, Böer and coworkers reported the overexpression of the tannase gene ATAN1 in the auxotrophic mutant strain Arxula adeninivorans G1212. The ATAN1 gene was under the control of the strong, constitutive TEF1 promoter, and its product was directed into the secretion pathway by its own 28-amino acid secretion sequence. The recombinant $A$. adeninivorans produced levels of up to $400 \mathrm{U} / \mathrm{L}$ when grown in glucose medium in shake flasks. Whereas the wild type strain LS3 secreted amounts of tannase equivalent to $100 \mathrm{U} / \mathrm{L}$ under inducing conditions [21].

On the other hand, Iwamoto et al. [40] identified the tannase-encoding gene from Lactobacillus plantarum. The tannase gene was cloned and hyperexpressed in Escherichia coli; the recombinant tannase was further purified through several chromatographic steps and biochemically characterized. For improving the purification of the recombinant $L$. plantarum tannase, Curiel and coworkers used the vector pURI3 to express the tannase gene in E. coli. The pURI3 vector was created using the pT7-7 vector as template and contained an amino-terminal His-tag that allowed the purification of the recombinant protein directly from the crude cell extracts in a single-step procedure [20].

Moreover, Yao et al. [149] isolated a novel gene encoding tannase $(\tan 410)$ from a cotton field metagenomic library by functional screening. The $\tan 410$ gene was cloned and expressed in $E$. coli as an N-terminal His-tag fusion protein using pET-28a expression system under the control of T7 lac promoter. The recombinant tannase was purified and characterized, and it was found to have interesting properties for biotechnological applications.

\section{Downstream Processing of Tannase}

In the previous section, it was established the need for improvement of the tannase production processes (upstream processing). Another important aspect on industrial tannase manufacture is the downstream processing operations.
Downstream processing of proteins involves all the operations after the production process that is, recovery, concentration, and purification. The number and the type of these operations depend on the nature of the raw material and the necessary purity in the final product. Anyway, during the downstream processing, it should not lose more of the product than that absolutely necessary [150].

In the case of tannase, there are a number of papers describing different protocols for enzyme recovery, concentration, and purification. Most of them are focused in the purification of tannase for analytical purposes, such as biochemical or molecular characterization. These protocols are useful for obtaining high-purity protein, but the operations utilized are slow, expensive, and inefficient for industrial purposes. The degree of purity required for industrial enzymes is much lower. It is often sufficient that the purity of the enzyme ensures the stability and the absence of undesirable reactions. In other cases, it also must be guaranted the product safety. Thus, it should be designed specific protocols for enzyme purification for industrial applications. In this section, the main advances in downstream processing of tannase will be discussed.

6.1. Recovery. The method for tannase recovery depends on the production system, the microorganism used, and the time of extraction. In SSF, tannase is produced mainly extracellularly and recovery is easily achieved, simply add two or three volumes of extractant (distilled water or buffer) mixing and compression, to obtain an enzyme extract. In the case of the SmF, the location of the enzyme depends on the microorganism and the incubation time [3].

In SmF, fungi produce intracellular tannase during the first hours of incubation. At this stage, enzyme recovery implies cell disruption and extraction with an appropriate agent. Tannase is lately excreted, making its recovery easy. However, at the moment of maximal production, $75 \%$ of the enzyme remains bound on the mycelium [59]. On the other hand, most of the bacterial strains produce extracellular tannase in SmF. However, recently, it has been found an interesting cell-associated tannase from Serratia ficaria produced in $\mathrm{SmF}[8]$.

Cell disruption may be achieved by chemical, enzymatic, or mechanical procedures. Barthomeuf et al. [109] reported that the classical physical and chemical methods were unable to release the tannase attached to the Aspergillus niger mycelium. No more than $5 \%$ of the enzyme was recovered by grinding mycelium with sand or glass beads or pulverizing with a homogenizer; osmotic shocks or ultrasonic waves in various buffers neither were productive. For the efficient recovery of this mycelium-bound tannase, they proposed an enzymatic hydrolysis of cell walls using a chitinase from Streptomyces griseus followed by reverse micellar extraction. This protocol resulted in a recovery of $43 \%$ active enzyme.

On the other hand, Bhardwaj and coworkers found that tannase extraction from the mycelium of Aspergillus niger strongly depends on the $\mathrm{pH}$ of the extractant agent and that maximum enzyme recovery is reached at $\mathrm{pH}$ 5.5. In addition, they found that homogenization and detergent 
pretreatments do not have any remarkable effect on the extraction of tannase [151].

6.2. Concentration. Water is considered as a major contaminant in enzyme preparations, particularly in those that are excreted to a fermentation broth. Thus, protein concentration operations are often the first step in protein purification protocols.

Traditionally, tannase concentration has been carried out by precipitation with salts or solvents. These techniques are simple, rapid, economical, and do not require sophisticated equipment. But they often lead to low-recovery yield of enzymatic activity due to irreversible denaturation of protein. For example, Battestin and Macedo concentrated a Paecilomyces variotii tannase by sulfate precipitation; they obtained a 1.9fold purification with a recovery yield of $34 \%$ [81]. Lekha and Lonsane [133] precipitated an Aspergillus niger GH1 with acetone. They obtained a 6.2-fold purification but with a low recovery yield of $28 \%$.

Another method utilized for downstream processing of tannase is the concentration with polyethylene glycol. The enzymatic extract is put into a dialysis membrane bag and placed on a layer of PEG 6000 [76]. This technique allows a rapid and efficient concentration and does not require any specialized equipment. But the method has several complications, especially for scaling up. Enemuor and Odibo used a variation of this methodology for tannase concentration. They assayed the dialysis of an enzymatic extract against $6 \mathrm{M}$ sucrose and obtained a 23-fold concentration. However, the recovery yield was extremely low (1.9\%) [153].

On the other hand, ultrafiltration has been used to efficiently concentrate tannase. This technique is rapid and leads to a high-recovery yield. In addition, when using appropriate membranes, ultrafiltration can be used for simultaneous concentration and purification of proteins. It has the disadvantage of requiring specialized equipment but then can be used on a large-scale downstream processing. Sharma and coworkers reported the use of ultrafiltration for the concentration of a Paecilomyces variotii tannase. They utilized a $100 \mathrm{kDa}$ MWCO membrane and concentrated 5.4 times the crude extract. Using this methodology, they achieved a 5.2fold purification with a recovery yield of $97 \%$ [32].

6.3. Purification. The purification process is one of the less developed aspects on tannase. Most of the published purification protocols consist on multistep procedures able to obtain a highly purified enzyme but with a low-recovery yield. Table 4 summarizes several protocols utilized for this aim.

Probably the most common strategy used for the purification of tannase based on protein concentration followed by ion exchange and/or gel filtration chromatography [7, $151,152]$. Sharma and coworkers purified to homogeneity the intracellular tannase from Aspergillus niger MTCC 2425. They designed a protocol consisting in protein concentration with polyethylene glycol followed by ionic exchange chromatography in a DEAE-cellulose column and gel filtration using a Sephadex G-150 column. This strategy led to a highpurity enzyme but with a low-recovery yield (2.7\%) [76].
The efficiency of a purification protocol mainly depends on the number and the type of operations utilized. But this is not the only important factor; the order of operations can drastically affect the process performance. Bhardwaj et al. [151] improved the above-mentioned protocol by changing the order of chromatographic steps. This strategy helped to overcome the problem of binding of fungal pigment to the matrix of DEAE column; since the fungal pigment did not bind to Sephadex G-150 and was eluted after the proteins, the performance of ionic exchange chromatography was improved.

Other authors have applied more sophisticated technologies for tannase purification. Beverini and Metche [58] purified two isoforms of tannase from a commercial enzyme powder prepared from culture broth of Aspergillus oryzae. They subsequently used precipitation with acetone, gel filtration on Sephadex G-50 and Biogel P-300 columns, and affinity chromatography on Con-A Ultrogel. Ramírez-Coronel and coworkers purified an $A$. niger tannase by preparative isoelectric focusing followed by ionic exchange (MonoQ column) and gelfiltration chromatography (Sephadex G-100) [42].

Another interesting approach is related to the purification of recombinant tannases. Zhong and coworkers reported that the recombinant tannase from Aspergillus oryzae expressed in Pichia pastoris was easily purified to homogeneity. They purified the enzyme by ultrafiltration followed by ionic exchange and obtained $72 \mathrm{mg}$ of pure protein from $1000 \mathrm{~mL}$ of culture broth $(50 \mathrm{U} / \mathrm{mg})$ with a recovery yield about $50 \%$ [23]. Curiel et al. described a high-yield protocol for the purification of a recombinant Lactobacillus plantarum tannase expressed in Escherichia coli. The protein was cloned containing an affinity hexa-His tag, this allowed to purify the recombinant tannase directly from the crude extract using a His-Trap-FF chelating column. By this strategy, they obtained high amounts of pure recombinant tannase $(17 \mathrm{mg} / \mathrm{L})$ by a one-step affinity procedure [20] .

On the other hand, a few authors have developed strategies for downstream processing of tannase based on rapid, economic, and easily scalable unit operations. Gupta and coworkers developed a rapid procedure for partial purification of extracellular tannase based on the precipitation of protein with a combination of tannic acid and PEG-6000. They obtained eightfold purification by a twostep protocol and a recovery yield about 50\% [25]. Naidu et al. Partially purified an Aspergillus oryzae by a procedure involving ammonium precipitation and liquid-liquid extraction in aqueous two-phase systems [26]. This protocol led to a purification fold of 2.70 and yield of $82.0 \%$. These strategies are simple and convenient. Therefore, they have potential application in the processing of tannase for industrial use, where absolute purity is not necessary, or in the early stages of a total purification.

\section{Concluding Remarks}

Tannase is an enzyme with a number of potential applications in biotechnology. However, many of these applications 
TABLE 4: Summary of protocols for tannase purification.

\begin{tabular}{|c|c|c|c|c|c|c|}
\hline Source & $\begin{array}{c}\text { Production } \\
\text { system }\end{array}$ & $\begin{array}{l}\text { Extra-/intra- } \\
\text { cellular }\end{array}$ & Operations & $\begin{array}{l}\text { Purification } \\
\text { factor }\end{array}$ & $\begin{array}{l}\text { Recovery yield } \\
(\%)\end{array}$ & Reference \\
\hline $\begin{array}{l}\text { Aspergillus } \\
\text { awamori }\end{array}$ & $\mathrm{SmF}$ & Extracellular & $\begin{array}{l}\text { Aluminum oxide treatment, } \\
\text { ultrafiltration ( } 30 \text { and } 100 \mathrm{kDa}) \text {, and gel } \\
\text { filtration (Sephadex G-200). }\end{array}$ & 6.32 & 0.51 & {$[37]$} \\
\hline $\begin{array}{l}\text { Aspergillus } \\
\text { flavus }\end{array}$ & $\mathrm{SmF}$ & Intracellular & $\begin{array}{l}\text { Ammonium sulfate and tannic acid } \\
\text { precipitation, ionic exchange } \\
\text { (DEAE-cellulose), gel filtration } \\
\text { chromatography (Sephadex G-200), and } \\
\text { acetone fractionation. }\end{array}$ & 31 & 49 & {$[73]$} \\
\hline $\begin{array}{l}\text { Aspergillus } \\
\text { foetidus }\end{array}$ & $\mathrm{SmF}$ & Extracellular & $\begin{array}{l}\text { Ammonium sulfate precipitation and } \\
\text { ATPS extraction }\end{array}$ & 2.7 & 82.5 & {$[26]$} \\
\hline $\begin{array}{l}\text { Aspergillus } \\
\text { heteromorphus }\end{array}$ & $\mathrm{SmF}$ & Extracellular & $\begin{array}{l}\text { Ammonium sulfate precipitation and } \\
\text { ionic exchange chromatography } \\
\text { (DEAE-cellulose) }\end{array}$ & 39.7 & 19.3 & {$[7]$} \\
\hline $\begin{array}{l}\text { Aspergillus } \\
\text { niger }\end{array}$ & $\mathrm{SmF}$ & Intracellular & $\begin{array}{l}\text { Ultrafiltration ( } 100 \text { and } 200 \mathrm{kDa} \text { ) and } \\
\text { high-pressure size-exclusion } \\
\text { chromatography (SW 300). }\end{array}$ & 29.1 & 15.1 & [59] \\
\hline $\begin{array}{l}\text { Aspergillus } \\
\text { niger }\end{array}$ & $\mathrm{SmF}$ & Intracellular & $\begin{array}{l}\text { Concentration with PEG 6000, ionic } \\
\text { exchange (DEAE-Sephadex), and gel } \\
\text { filtration chromatography (Sephadex } \\
\text { G-150). }\end{array}$ & 29 & 2.7 & {$[76]$} \\
\hline $\begin{array}{l}\text { Aspergillus } \\
\text { niger }\end{array}$ & $\mathrm{SmF}$ & Intracellular & $\begin{array}{l}\text { Gel filtration (Sephadex G-150) and ionic } \\
\text { exchange chromatography } \\
\text { (DEAE-Sephadex). }\end{array}$ & 51 & 20 & [151] \\
\hline $\begin{array}{l}\text { Aspergillus } \\
\text { niger }\end{array}$ & SSF & Extracellular & $\begin{array}{l}\text { Ultrafiltration ( } 1 \mathrm{kDa}) \text {, ionic exchange } \\
\text { (DEAE-cellulose), and gel filtration } \\
\text { chromatography (Sephacryl S-300). }\end{array}$ & 46 & 0.3 & {$[31]$} \\
\hline $\begin{array}{l}\text { Aspergillus } \\
\text { oryzae }\end{array}$ & $\mathrm{SmF}$ & Extracellular & $\begin{array}{l}\text { Ionic exchange (DEAE-Sephadex), gel } \\
\text { filtration (Sephadex G100), } \\
\text { ultracentrifugation. }\end{array}$ & 12.8 & 11.5 & [69] \\
\hline Candida sp. & $\mathrm{SmF}$ & Extracellular & $\begin{array}{l}\text { Pervaporation, rivanol precipitation, } \\
\text { ionic exchange (ECTEOLA-cellulose), } \\
\text { ultrafiltration, and gel filtration } \\
\text { chromatography (Sepharose } 6 \text { B and } \\
\text { Sephadex G200). }\end{array}$ & 613 & 7.3 & {$[78]$} \\
\hline Enterobacter sp. & $\mathrm{SmF}$ & Intracellular & $\begin{array}{l}\text { Ammonium sulfate precipitation, ionic } \\
\text { exchange (DEAE-cellulose) and gel } \\
\text { filtration chromatography (Sephadex } \\
\text { G-100). }\end{array}$ & 162 & 7.1 & [39] \\
\hline $\begin{array}{l}\text { Lactobacillus } \\
\text { plantarum in } \\
\text { E. coli }\end{array}$ & $\mathrm{SmF}$ & Intracellular & $\begin{array}{l}\text { Ammonium sulfate precipitation and } \\
\text { three ionic exchange chromatographic } \\
\text { steps (Q Sepharose, Hydroxyapatite, and } \\
\text { Mono Q columns). }\end{array}$ & 11.2 & 4.8 & {$[40]$} \\
\hline $\begin{array}{l}\text { Lactobacillus } \\
\text { plantarum in } \\
\text { E. coli }\end{array}$ & $\mathrm{SmF}$ & Intracellular & $\begin{array}{l}\text { Affinity chromatography (poorly } \\
\text { activated nickel chelate supports). }\end{array}$ & 15 & 95 & {$[27]$} \\
\hline $\begin{array}{l}\text { Paecilomyces } \\
\text { variotii }\end{array}$ & $\mathrm{SmF}$ & Extracellular & $\begin{array}{l}\text { Activated charcoal treatment, } \\
\text { ammonium sulfate precipitation, ionic } \\
\text { exchange (DEAE-cellulose), and gel } \\
\text { filtration chromatography (Sephadex } \\
\text { G-200). }\end{array}$ & 30.5 & 17.6 & {$[152]$} \\
\hline $\begin{array}{l}\text { Paecilomyces } \\
\text { variotii }\end{array}$ & SSF & Extracellular & $\begin{array}{l}\text { Ammonium sulfate precipitation and } \\
\text { ionic exchange chromatography } \\
\text { (DEAE-Sepharose). }\end{array}$ & 19.3 & 3 & {$[34]$} \\
\hline
\end{tabular}


TABle 4: Continued.

\begin{tabular}{|c|c|c|c|c|c|c|}
\hline Source & $\begin{array}{c}\text { Production } \\
\text { system }\end{array}$ & $\begin{array}{l}\text { Extra-/intra- } \\
\text { cellular }\end{array}$ & Operations & $\begin{array}{c}\text { Purification } \\
\text { factor }\end{array}$ & $\begin{array}{c}\text { Recovery yield } \\
(\%)\end{array}$ & Reference \\
\hline $\begin{array}{l}\text { Penicillium } \\
\text { chrysogenum }\end{array}$ & $\mathrm{SmF}$ & Intracellular & $\begin{array}{l}\text { Ammonium sulfate precipitation, ionic } \\
\text { exchange (DEAE-cellulose), and gel } \\
\text { filtration chromatography (Sephadex } \\
\text { G-200). }\end{array}$ & 24 & 18.5 & {$[80]$} \\
\hline $\begin{array}{l}\text { Penicillium } \\
\text { variable }\end{array}$ & $\mathrm{SmF}$ & Extracellular & $\begin{array}{l}\text { Ultrafiltration }(100 \mathrm{kDa}) \text { and gel } \\
\text { filtration chromatography (Sephadex } \\
\text { G-200). }\end{array}$ & 135 & 91 & {$[32]$} \\
\hline $\begin{array}{l}\text { Verticillium sp. } \\
\text { (TAH 1) }\end{array}$ & $\mathrm{SmF}$ & Extracellular & $\begin{array}{l}\text { Ammonium sulfate precipitation and } \\
\text { ionic exchange chromatography } \\
\text { (DEAE-cellulose). }\end{array}$ & 7.9 & 1.6 & {$[12]$} \\
\hline $\begin{array}{l}\text { Verticillium sp. } \\
\text { (TAH 2) }\end{array}$ & $\mathrm{SmF}$ & Extracellular & $\begin{array}{l}\text { Ammonium sulfate precipitation and } \\
\text { ionic exchange chromatography } \\
\text { (DEAE-cellulose). }\end{array}$ & 10.5 & 0.9 & {$[12]$} \\
\hline
\end{tabular}

have been missed due to the high cost of the enzyme. In this regard, in recent years, it has been made significant progress for improving the upstream and downstream processing of tannase. Several research groups have developed economic and ecofriendly processes for the production and purification of the enzyme at laboratory level. On the other hand, the use of modern techniques of molecular biology has allowed the development of highly efficient processes for production and recovery of the enzyme, and this appear to be the trend to continue in the coming years. The results have been positive, but more research is needed on basic and applied aspects of tannase, such as regulation of the enzyme, metagenomics, new expression systems, design of new bioprocesses using emerging large-scale cultivation technologies, efficient and cost-effective downstream processing and design of new applications for the enzyme such as the production of antioxidants from waste materials or the bioremediation of tannery effluents.

\section{Acknowledgments}

The authors thank the Mexican National Council on Science and Technology (CONACYT) for funding this study. Luis V. Rodríguez thanks CONACYT for the financial support provided for their postgraduate studies in the Food Science and Technology Program, Universidad Autónoma de Coahuila.

\section{References}

[1] H. Rodríguez, J. A. Curiel, J. M. Landete et al., "Food phenolics and lactic acid bacteria," International Journal of Food Microbiology, vol. 132, no. 2-3, pp. 79-90, 2009.

[2] L. Ramírez, J. Arrizon, G. Sandoval et al., "A new microplate screening method for the simultaneous activity quantification of feruloyl esterases, tannases, and chlorogenate esterases," Applied Biochemistry and Biotechnology, vol. 151, no. 2-3, pp. 711-723, 2008.

[3] C. N. Aguilar, R. Rodríguez, G. Gutiérrez-Sánchez et al., "Microbial tannases: Advances and perspectives," Applied Microbiology and Biotechnology, vol. 76, no. 1, pp. 47-59, 2007.
[4] C. N. Aguilar and G. Gutiérrez-Sánchez, "Review: sources, properties, applications and potential uses of tannin acyl hydrolase," Food Science and Technology International, vol. 7, no. 5, pp. 373-382, 2001.

[5] M. Cruz-Hernández, J. C. Contreras-Esquivel, F. Lara, R. Rodríguez, and C. N. Aguilar, "Isolation and evaluation of tannin-degrading fungal strains from the Mexican desert," Zeitschrift fur Naturforschung. Section C, Journal of Biosciences, vol. 60, no. 11-12, pp. 844-848, 2005.

[6] S. Mahapatra and D. Banerjee, "Extracellular tannase production by endophyitc Hyalopus sp," Journal of General and Applied Microbiology, vol. 55, no. 3, pp. 255-259, 2009.

[7] V. Chhokar, Seema, V. Beniwal et al., "Purification and characterization of extracellular tannin acyl hydrolase from Aspergillus heteromorphus MTCC 8818," Biotechnology and Bioprocess Engineering, vol. 15, no. 5, pp. 793-799, 2010.

[8] P. D. Belur, M. Gopal, K. R. Nirmala, and N. Basavaraj, "Production of novel cell-associated tannase from newly isolated Serratia ficaria DTC," Journal of Microbiology and Biotechnology, vol. 20, no. 4, pp. 732-736, 2010.

[9] M. Pepi, L. R. Lampariello, R. Altieri et al., "Tannic acid degradation by bacterial strains Serratia spp. and Pantoea sp. isolated from olive mill waste mixtures," International Biodeterioration and Biodegradation, vol. 64, no. 1, pp. 73-80, 2010.

[10] N. Y. Sariozlu and M. Kivanc, "Isolation of gallic acidproducing microorganisms and their use in the production of gallic acid from gall nuts and sumac," African Journal of Biotechnology, vol. 8, no. 6, pp. 1110-1115, 2009.

[11] R. A. Peterson, J. R. Bradner, T. H. Roberts, and K. M. H. Nevalainen, "Fungi from koala (Phascolarctos cinereus) faeces exhibit a broad range of enzyme activities against recalcitrant substrates," Letters in Applied Microbiology, vol. 48, no. 2, pp. 218-225, 2009.

[12] M. Kasieczka-Burnecka, K. Kuc, H. Kalinowska, M. Knap, and M. Turkiewicz, "Purification and characterization of two cold-adapted extracellular tannin acyl hydrolases from an Antarctic strain Verticillium sp. P9," Applied Microbiology and Biotechnology, vol. 77, no. 1, pp. 77-89, 2007.

[13] J. S. Purohit, J. R. Dutta, R. K. Nanda, and R. Banerjee, "Strain improvement for tannase production from coculture of Aspergillus foetidus and Rhizopus oryzae," Bioresource Technology, vol. 97, no. 6, pp. 795-801, 2006. 
[14] J. van de Lagemaat and D. L. Pyle, "Solid-state fermentation: a continuous process for fungal tannase production," Biotechnology and Bioengineering, vol. 87, no. 7, pp. 924-929, 2004.

[15] B. Kar and R. Banerjee, "Biosynthesis of tannin acyl hydrolase from tannin-rich forest residue under different fermentation conditions," Journal of Industrial Microbiology and Biotechnology, vol. 25, no. 1, pp. 29-38, 2000.

[16] N. Raaman, B. Mahendran, C. Jaganathan, S. Sukumar, and V. Chandrasekaran, "Optimisation of extracellular tannase production from Paecilomyces variotii," World Journal of Microbiology and Biotechnology, vol. 26, no. 6, pp. 1033-1039, 2010.

[17] M. Selwal, A. Yadav, K. Selwal, N. Aggarwal, R. Gupta, and S. Gautam, "Optimization of cultural conditions for tannase production by Pseudomonas aeruginosa IIIB 8914 under submerged fermentation," World Journal of Microbiology and Biotechnology, vol. 26, no. 4, pp. 599-605, 2010.

[18] R. Paranthaman, R. Vidyalakshmi, S. Murugesh, and K. Singaravadivel, "Manipulation of fermentation conditions on production of tannase from agricultural by-products with Aspergillus oryzae," African Journal of Microbiology Research, vol. 4, no. 13, pp. 1440-1445, 2010.

[19] P. K. Das Mohapatra, C. Maity, R. S. Rao, B. R. Pati, and K. C. Mondal, "Tannase production by Bacillus licheniformis KBR6: optimization of submerged culture conditions by Taguchi DOE methodology," Food Research International, vol. 42, no. 4, pp. 430-435, 2009.

[20] J. A. Curiel, H. Rodríguez, I. Acebrón, J. M. Mancheño, L. de Blanca Rivas, and R. Muñoz, "Production and physicochemical properties of recombinant Lactobacillus plantarum tannase," Journal of Agricultural and Food Chemistry, vol. 57, no. 14, pp. 6224-6230, 2009.

[21] E. Böer, R. Bode, H. P. Mock, M. Piontek, and G. Kunze, "Atan 1p-an extracellular tannase from the dimorphic yeast Arxula adeninivorans: molecular cloning of the ATAN1 gene and characterization of the recombinant enzyme," Yeast, vol. 26, no. 6, pp. 323-337, 2009.

[22] X. W. Yu and Y. Q. Li, "Expression of Aspergillus oryzae tannase in Pichia pastoris and its application in the synthesis of propyl gallate in organic solvent," Food Technology and Biotechnology, vol. 46, no. 1, pp. 80-85, 2008.

[23] X. Zhong, L. Peng, S. Zheng et al., "Secretion, purification, and characterization of a recombinant Aspergillus oryzae tannase in Pichia pastoris," Protein Expression and Purification, vol. 36, no. 2, pp. 165-169, 2004.

[24] E. H. Albertse, Cloning, expresion and caracterization of tannase from Aspergillus species, M.S. thesis, Department of Microbiology and Biochemistry, Faculty of Natural and Agricultural Sciences, University of the Free State, Bloemfontein, South Africa, 2002.

[25] R. Gupta, S. Bradoo, and R. K. Saxena, "Rapid purification of extracellular tannase using polyethylene glycol-tannic acid complex," Letters in Applied Microbiology, vol. 24, no. 4, pp. 253-255, 1997.

[26] R. B. Naidu, N. Saisubramanian, D. Selvakumar, S. Janardhanan, and R. Puvanakrishnan, "Partial purification of tannase from Aspergillus foetidus by aqueous two phase extraction and its characterization," Current Trends in Biotechnology and Pharmacy, vol. 2, no. 1, pp. 201-207, 2008.

[27] J. A. Curiel, L. Betancor, B. de las Rivas, R. Muñoz, J. M. Guisan, and G. Fernández-Lorente, "Hydrolysis of tannic acid catalyzed by immobilized-stabilized derivatives of tannase from Lactobacillus plantarum," Journal of Agricultural and Food Chemistry, vol. 58, no. 10, pp. 6403-6409, 2010.

[28] C. N. Aguilar, C. Augur, E. Favela-Torres, and G. ViniegraGonzález, "Production of tannase by Aspergillus niger Aa20 in submerged and solid-state fermentation: influence of glucose and tannic acid," Journal of Industrial Microbiology and Biotechnology, vol. 26, no. 5, pp. 296-302, 2001.

[29] C. N. Aguilar, C. Augur, E. Favela-Torres, and G. ViniegraGonzález, "Induction and repression patterns of fungal tannase in solid-state and submerged cultures," Process Biochemistry, vol. 36, no. 6, pp. 565-570, 2001.

[30] V. Chhokar, M. Sangwan, V. Beniwal, K. Nehra, and K. S. Nehra, "Effect of additives on the activity of tannase from Aspergillus awamori MTCC9299," Applied Biochemistry and Biotechnology, vol. 160, no. 8, pp. 2256-2264, 2010.

[31] M. A. Mata-Gómez, L. V. Rodríguez, E. L. Ramos et al., “A novel tannase from the xerophilic fungus Aspergillus niger GH1," Journal of Microbiology and Biotechnology, vol. 19, no. 9, pp. 987-996, 2009.

[32] S. Sharma, L. Agarwal, and R. K. Saxena, "Purification, immobilization and characterization of tannase from Penicillium variable," Bioresource Technology, vol. 99, no. 7, pp. 2544-2551, 2008.

[33] H. Rodríguez, B. de las Rivas, C. Gómez-Cordovés, and R. Muñoz, "Characterization of tannase activity in cell-free extracts of Lactobacillus plantarum CECT 748T," International Journal of Food Microbiology, vol. 121, no. 1, pp. 92-98, 2008.

[34] V. Battestin and G. A. Macedo, "Purification and biochemical characterization of tannase from a newly isolated strain of Paecilomyces variotii," Food Biotechnology, vol. 21, no. 3, pp. 207-216, 2007.

[35] V. Battestin, G. A. S. Pinto, and G. A. Macedo, "Biochemical characterization of tannases from Paecilomyces variotii and Aspergillus niger," Food Science and Biotechnology, vol. 16, no. 2, pp. 243-248, 2007.

[36] N. Noguchi, T. Ohashi, T. Shiratori et al., "Association of tannase-producing Staphylococcus lugdunensis with colon cancer and characterization of a novel tannase gene," Journal of Gastroenterology, vol. 42, no. 5, pp. 346-351, 2007.

[37] P. S. Beena, M. B. Soorej, K. K. Elyas, G. B. Sarita, and M. Chandrasekaran, "Acidophilic tannase from marine Aspergillus awamori BTMFW032," Journal of Microbiology and Biotechnology, vol. 20, no. 10, pp. 1403-1414, 2010.

[38] F. León-Galván, I. Torres-Pacheco, F. Jiménez-Espinoza et al., "Molecular and biochemical characterization of extracellular tannin acyl hydrolase activity from a mexican isolate of Aspergillus niger," Journal of Scientific and Industrial Research, vol. 69, no. 12, pp. 942-947, 2011.

[39] K. P. Sharma and P. J. John, "Purification and characterization of tannase and tannase gene from Enterobacter sp," Process Biochemistry, vol. 46, no. 1, pp. 240-244, 2011.

[40] K. Iwamoto, H. Tsuruta, Y. Nishitaini, and R. Osawa, "Identification and cloning of a gene encoding tannase (tannin acylhydrolase) from Lactobacillus plantarum ATCC 14917T," Systematic and Applied Microbiology, vol. 31, no. 4, pp. 269277, 2008.

[41] Y. Nishitani, E. Sasaki, T. Fujisawa, and R. Osawa, "Genotypic analyses of lactobacilli with a range of tannase activities isolated from human feces and fermented foods," Systematic and Applied Microbiology, vol. 27, no. 1, pp. 109-117, 2004. 
[42] M. A. Ramírez-Coronel, G. Viniegra-González, A. Darvill, and C. Augur, "A novel tannase from Aspergillus niger with $\beta$ glucosidase activity," Microbiology, vol. 149, no. 10, pp. 29412946, 2003.

[43] O. Hatamoto, T. Watarai, M. Kikuchi, K. Mizusawa, and H. Sekine, "Cloning and sequencing of the gene encoding tannase and a structural study of the tannase subunit from Aspergillus oryzae," Gene, vol. 175, no. 1-2, pp. 215-221, 1996.

[44] C. Rusniok, E. Couvé, V. Da Cunha et al., "Genome sequence of Streptococcus gallolyticus: insights into its adaptation to the bovine rumen and its ability to cause endocarditis," Journal of Bacteriology, vol. 192, no. 8, pp. 2266-2276, 2010.

[45] A. A. Bele, V. M. Jadhav, and V. J. Kadam, "Potential of tannnins: a review," Asian Journal of Plant Sciences, vol. 9, no. 4, pp. 209-214, 2010.

[46] P. Frutos, G. Hervás, F. J. Giráldez, and A. R. Mantecón, "Review. Tannins and ruminant nutrition," Spanish Journal of Agricultural Research, vol. 2, no. 2, pp. 191-202, 2004.

[47] W. Bors and C. Michel, "Antioxidant capacity of flavanols and gallate esters: pulse radiolysis studies," Free Radical Biology and Medicine, vol. 27, no. 11-12, pp. 1413-1426, 1999.

[48] M. E. Carretero-Accame, "Compuestos fenólicos: taninos," Panorama Actual del Medicamento, vol. 24, no. 235, pp. 633636,2000

[49] K. Khanbabaee and T. van Ree, "Tannins: classification and definition," Natural Product Reports, vol. 18, no. 6, pp. 641649, 2001.

[50] R. Belmares, J. C. Contreras-Esquivel, R. Rodríguez-Herrera, A. R. Coronel, and C. N. Aguilar, "Microbial production of tannase: An enzyme with potential use in food industry," LWT-Food Science and Technology, vol. 37, no. 8, pp. 857864, 2004.

[51] L. Mingshu, Y. Kai, H. Qiang, and J. Dongying, "Biodegradation of gallotannins and ellagitannins," Journal of Basic Microbiology, vol. 46, no. 1, pp. 68-84, 2006.

[52] P. K. Lekha and B. K. Lonsane, "Production and application of tannin acyl hydrolase: state of the art," in Advances in Applied Microbiology, S. Neidleman and A. Laskin, Eds., vol. 44, pp. 215-260, Academic Press, San Diego, Calif, USA, 1997.

[53] J. A. Field and G. Lettinga, "Biodegradation of tannins," in Metal Ions in Biological Systems: Degradation of Environmental Pollutants by Microorganisms and Their Metalloenzymes, H. Sigel, Ed., vol. 28, pp. 61-97, Marcel Dekker, New York, NY, USA, 1992.

[54] T. K. Bhat, B. Singh, and O. P. Sharma, "Microbial degradation of tannins-a current perspective," Biodegradation, vol. 9, no. 5, pp. 343-357, 1998.

[55] E. Haslam and J. E. Stangroom, "The esterase and depsidase activities of tannase," Biochemical Journal, vol. 99, no. 1, pp. 28-31, 1966.

[56] J. U. Niehaus and G. G. Gross, "A gallotannin degrading esterase from leaves of pedunculate oak," Phytochemistry, vol. 45, no. 8, pp. 1555-1560, 1997.

[57] G. Toth and J. Barsony, "Uber die chromatographie der tannase," Enzymologia, vol. 11, no. 1, pp. 19-23, 1943.

[58] M. Beverini and M. Metche, "Identification, purification, physiochemical properties of tannase from Aspergillus oryzae," Science des Aliments, vol. 10, no. 1, pp. 807-816, 1990.

[59] C. Barthomeuf, F. Regerat, and H. Pourrat, "Production, purification and characterization of a tannase from Aspergillus niger LCF 8," Journal of Fermentation and Bioengineering, vol. 77, no. 3, pp. 320-323, 1994.
[60] S. Iibuchi, Y. Minoda, and K. Yamada, "Hydrolyzing pathway, substrate specificity and inhibition of tannin acyl hydrolase of Aspergillus oryzae no. 7," Agricultural and Biological Chemistry, vol. 36, no. 9, pp. 1553-1562, 1972.

[61] G. Iacazio, C. Périssol, and B. Faure, "A new tannase substrate for spectrophotometric assay," Journal of Microbiological Methods, vol. 42, no. 3, pp. 209-214, 2000.

[62] M. T. García-Conesa, P. Østergaard, S. Kauppinen, and G. Williamson, "Hydrolysis of diethyl diferulates by a tannase from Aspergillus oryzae," Carbohydrate Polymers, vol. 44, no. 4, pp. 319-324, 2001.

[63] M. J. Lu and C. Chen, "Enzymatic tannase treatment of green tea increases in vitro inhibitory activity against $\mathrm{N}$-nitrosation of dimethylamine," Process Biochemistry, vol. 42, no. 9, pp. 1285-1290, 2007.

[64] Y.-J. Zhang, T. Abe, T. Tanaka, C. R. Yang, and I. Kouno, "Phyllanemblinins A-F, new ellagitannins from Phyllanthus emblica," Journal of Natural Products, vol. 64, no. 12, pp. 1527-1532, 2001.

[65] Y. Fukui, K. Nomoto, T. Iwashita, K. Masuda, Y. Tanaka, and T. Kusumi, "Two novel blue pigments with ellagitannin moiety, rosacyanins A1 and A2, isolated from the petals of Rosa hybrida," Tetrahedron, vol. 62, no. 41, pp. 9661-9670, 2006.

[66] T. Koseki, K. Mihara, T. Murayama, and Y. Shiono, "A novel Aspergillus oryzae esterase that hydrolyzes 4-hydroxybenzoic acid esters," FEBS Letters, vol. 584, no. 18, pp. 4032-4036, 2010.

[67] K. Aoki, R. Shinke, and H. Nishira, "Chemical composition and molecular weight of yeast tannase," Agricultural and Biological Chemistry, vol. 40, no. 2, pp. 297-302, 1976.

[68] I. K. Skene and J. D. Brooker, "Characterization of tannin acylhydrolase activity in the ruminal bacterium Selenomonas ruminantium," Anaerobe, vol. 1, no. 6, pp. 321-327, 1995.

[69] S. Iibuchi, Y. Minoda, and K. Yamada, "Studies on tannin acyl hydrolase of microorganisms part III. Purification of the enzyme and some properties of it," Agricultural and Biological Chemistry, vol. 36, no. 7, pp. 803-809, 1968.

[70] K. Mahapatra, R. K. Nanda, S. S. Bag, R. Banerjee, A. Pandey, and G. Szakacs, "Purification, characterization and some studies on secondary structure of tannase from Aspergillus awamori nakazawa," Process Biochemistry, vol. 40, no. 10, pp. 3251-3254, 2005.

[71] O. Adachi, M. Watanabe, and H. Yamada, "Studies on fungal tannase part II. Physicochemical properties of tannase of Aspergillus flavus," Agricultural and Biological Chemistry, vol. 32, no. 9, pp. 1079-1085, 1968.

[72] D. H. Strumeyer and M. J. Malin, "Resistance of extracellular yeast invertase and other glycoproteins to denaturation by tannins," Biochemical Journal, vol. 118, no. 5, pp. 899-900, 1970.

[73] H. Yamada, O. Adachi, M. Watanabe, and N. Sato, "Studies on fungal tannase part I. Formation, purification and catalytic properties of tannase of Aspergillus flavus," Agricultural and Biological Chemistry, vol. 32, no. 9, pp. 1070-1078, 1968.

[74] N. K. Rana and T. K. Bhat, "Effect of fermentation system on the production and properties of tannase of Aspergillus niger van Tieghem MTCC 2425," Journal of General and Applied Microbiology, vol. 51, no. 4, pp. 203-212, 2005.

[75] A. Sabu, G. S. Kiran, and A. Pandey, "Purification and characterization of tannin acyl hydrolase from Aspergillus niger ATCC 16620," Food Technology and Biotechnology, vol. 43, no. 2, pp. 133-138, 2005. 
[76] S. Sharma, T. K. Bhat, and R. K. Dawra, "Isolation, purification and properties of tannase from Aspergillus niger van Tieghem," World Journal of Microbiology and Biotechnology, vol. 15, no. 6, pp. 673-677, 1999.

[77] M. A. Abdel-Naby, A. A. Sherif, A. B. El-Tanash, and A. T. Mankarios, "Immobilization of Aspergillus oryzae tannase and properties of the immobilized enzyme," Journal of Applied Microbiology, vol. 87, no. 1, pp. 108-114, 1999.

[78] K. Aoki, R. Shinke, and H. Nishira, "Purification and some properties of yeast tannase," Agricultural and Biological Chemistry, vol. 40, no. 1, pp. 79-85, 1976.

[79] G. M. Farias, C. Gorbea, J. R. Elkins, and G. J. Griffin, "Purification, characterization, and substrate relationships of the tannase from Cryphonectria parasitica," Physiological and Molecular Plant Pathology, vol. 44, no. 1, pp. 51-63, 1994.

[80] G. Rajakumar and S. C. Nandy, "Isolation, purification, and some properties of Penicillium chrysogenum tannase," Applied and Environmental Microbiology, vol. 46, no. 2, pp. 525-527, 1983.

[81] V. Battestin and G. A. Macedo, "Effects of temperature, $\mathrm{pH}$ and additives on the activity of tannase produced by Paecilomyces variotii," Electronic Journal of Biotechnology, vol. 10, no. 2, pp. 191-199, 2007.

[82] N. Noguchi, K. Goto, T. Ro et al., "Using the tannase gene to rapidly and simply identify Staphylococcus lugdunensis," Diagnostic Microbiology and Infectious Disease, vol. 66, no. 1, pp. 120-123, 2010.

[83] E. Venditti, T. Bacchetti, L. Tiano, P. Carloni, L. Greci, and E. Damiani, "Hot vs. cold water steeping of different teas: do they affect antioxidant activity?" Food Chemistry, vol. 119, no. 4, pp. 1597-1604, 2010.

[84] W. Łuczaj and E. Skrzydlewska, "Antioxidative properties of black tea," Preventive Medicine, vol. 40, no. 6, pp. 910-918, 2005.

[85] T. Karak and R. M. Bhagat, "Trace elements in tea leaves, made tea and tea infusion: a review," Food Research International, vol. 43, no. 9, pp. 2234-2252, 2010.

[86] M. J. Lu, S. C. Chu, L. Yan, and C. Chen, "Effect of tannase treatment on protein-tannin aggregation and sensory attributes of green tea infusion," LWT-Food Science and Technology, vol. 42, no. 1, pp. 338-342, 2009.

[87] E. Su, T. Xia, L. Gao, Q. Dai, and Z. Zhang, "Immobilization and characterization of tannase and its haze-removing," Food Science and Technology International, vol. 15, no. 6, pp. 545$552,2009$.

[88] M. J. Lu and C. Chen, "Enzymatic modification by tannase increases the antioxidant activity of green tea," Food Research International, vol. 41, no. 2, pp. 130-137, 2008.

[89] S. Rout and R. Banerjee, "Production of tannase under mSSF and its application in fruit juice debittering," Indian Journal of Biotechnology, vol. 5, no. 3, pp. 346-350, 2006.

[90] A. Srivastava and R. Kar, "Characterization and application of tannase produced by Aspergillus niger ITCC 6514.07 on pomegranate rind," Brazilian Journal of Microbiology, vol. 40, no. 4, pp. 782-789, 2009.

[91] A. Srivastava and R. Kar, "Application of immobilized tannase from Aspergillus niger for the removal of tannin from myrobalan juice," Indian Journal of Microbiology, vol. 50, no. S1, pp. 46-51, 2010.

[92] R. Bel-Rhlid, K. Kraehenbuehl, C. Cavin, T. W. Raab, and N. Page, "Compositions for preparing a coffee beverage comprising hydrolysed chlorogenic acid," World Intellectual Property Organization Patent Application, no. WO09132887, 2009.
[93] C. Cantarelli, O. Brenna, G. Giovanelli, and M. Rossi, "Beverage stabilization through enzymatic removal of phenolics," Food Biotechnology, vol. 3, no. 2, pp. 203-213, 1989.

[94] Y.-Y. Ow and I. Stupans, "Gallic acid and gallic acid derivatives: effects on drug metabolizing enzymes," Current Drug Metabolism, vol. 4, no. 3, pp. 241-248, 2003.

[95] D. Banerjee, S. Mahapatra, and B. R. Pati, "Gallic acid production by submerged fermentation of Aspergillus aculeatus DBF9," Research Journal of Microbiology, vol. 2, no. 5, pp. 462-468, 2007.

[96] S. Martins, D. Mercado, M. Mata-Gómez et al., "Microbial production of potent phenolic-antioxidants through solid state fermentation," in Sustainable Biotechnology Springer Netherlands, O. V. Singh and S. P. Harvey, Eds., pp. 229-246, 2010.

[97] A. M. Deschamps and J. M. Lebeault, "Production of gallic acid from tara tannin by bacterial strains," Biotechnology Letters, vol. 6, no. 4, pp. 237-242, 1984.

[98] H. Pourrat, F. Regerat, P. Morvan, and A. Pourrat, "Microbiological production of gallic acid from Rhus coriaria L," Biotechnology Letters, vol. 9, no. 10, pp. 731-734, 1987.

[99] R. Banerjee, G. Mukherjee, and K. C. Patra, "Microbial transformation of tannin-rich substrate to gallic acid through co-culture method," Bioresource Technology, vol. 96, no. 8, pp. 949-953, 2005.

[100] B. Kar, R. Banerjee, and B. C. Bhattacharyya, "Microbial production of gallic acid by modified solid state fermentation," Journal of Industrial Microbiology and Biotechnology, vol. 23, no. 3, pp. 173-177, 1999.

[101] J. Ventura, G. Gutiérrez-Sanchez, R. Rodríguez-Herrera, and C. N. Aguilar, "Fungal cultures of tar bush and creosote bush for production of two phenolic antioxidants (pyrocatechol and gallic acid)," Folia Microbiologica, vol. 54, no. 3, pp. 199203, 2009.

[102] B. Bajpai and S. Patil, "A new approach to microbial production of gallic acid," Brazilian Journal of Microbiology, vol. 39, no. 4, pp. 708-711, 2008.

[103] B. Kar, R. Banerjee, and B. C. Bhattacharyya, "Optimization of physicochemical parameters for gallic acid production by evolutionary operation-factorial design technique," Process Biochemistry, vol. 37, no. 12, pp. 1395-1401, 2002.

[104] V. Battestin, G. A. Macedo, and V. A. P. de Freitas, "Hydrolysis of epigallocatechin gallate using a tannase from Paecilomyces variotii," Food Chemistry, vol. 108, no. 1, pp. 228-233, 2008.

[105] H. Weetall, "Enzymatic synthesis of gallic acid esters," Applied Biochemistry and Biotechnology, vol. 11, no. 1, pp. 25-28, 1985.

[106] T. Raab, R. Bel-Rhlid, G. Williamson, C. E. Hansen, and D. Chaillot, "Enzymatic galloylation of catechins in room temperature ionic liquids," Journal of Molecular Catalysis B: Enzymatic, vol. 44, no. 2, pp. 60-65, 2007.

[107] X. Yu, Y. Li, and D. Wu, "Enzymatic synthesis of gallic acid esters using microencapsulated tannase: effect of organic solvents and enzyme specificity," Journal of Molecular Catalysis B: Enzymatic, vol. 30, no. 2, pp. 69-73, 2004.

[108] X. W. Yu and Y. Q. Li, "Microencapsulated myceliumbound tannase from Aspergillus niger: an efficient catalyst for esterification of propyl gallate in organic solvents," Applied Biochemistry and Biotechnology, vol. 126, no. 3, pp. 177-187, 2005.

[109] C. Barthomeuf, F. Regerat, and H. Pourrat, "Improvement in tannase recovery using enzymatic disruption of mycelium in combination with reverse micellar enzyme extraction," Biotechnology Techniques, vol. 8, no. 2, pp. 137-142, 1994. 
[110] S. Sharma and M. N. Gupta, "Synthesis of antioxidant propyl gallate using tannase from Aspergillus niger van Teighem in nonaqueous media," Bioorganic and Medicinal Chemistry Letters, vol. 13, no. 3, pp. 395-397, 2003.

[111] R. Armitage, G. S. Bayliss, J. W. Gramshaw et al., "360. Gallotannins. Part III. The constitution of Chinese, Turkish, sumach, and tara tannins," Journal of the Chemical Society, pp. 1842-1853, 1961.

[112] T. Tanaka, G. I. Nonaka, M. Ishimatsu, I. Nishioka, and I. Kouno, "Revised structure of cercidinin A, a novel ellagitannin having (R)-hexahydroxydiphenoyl esters at the 3,4positions of glucopyranose," Chemical and Pharmaceutical Bulletin, vol. 49, no. 4, pp. 486-487, 2001.

[113] S. A. Ivanov, K. Nomura, I. L. Malfanov, I. V. Sklyar, and L. R. Ptitsyn, "Isolation of a novel catechin from Bergenia rhizomes that has pronounced lipase-inhibiting and antioxidative properties," Fitoterapia, vol. 82, no. 2, pp. 212-218, 2011.

[114] W. K. Krueger, H. Gutierrez-Bañuelos, G. E. Carstens et al., "Effects of dietary tannin source on performance, feed efficiency, ruminal fermentation, and carcass and noncarcass traits in steers fed a high-grain diet," Animal Feed Science and Technology, vol. 159, no. 1-2, pp. 1-9, 2010.

[115] O. M. Nuero and F. Reyes, "Enzymes for animal feeding from Penicillium chrysogenum mycelial wastes from penicillin manufacture," Letters in Applied Microbiology, vol. 34, no. 6, pp. 413-416, 2002.

[116] D. A. T. Southgate, "Vegetables, fruits, fungi and their products," in Human Nutrition and Dietetics, J. S. Garrow, W. P. T. James, and A. Ralph, Eds., pp. 349-362, Elsevier, Amsterdam, The Netherlands, 10th edition, 2000.

[117] M. Dueñas, T. Hernández, and I. Estrella, "Changes in the content of bioactive polyphenolic compounds of lentils by the action of exogenous enzymes. Effect on their antioxidant activity," Food Chemistry, vol. 101, no. 1, pp. 90-97, 2007.

[118] M. Dueñas, T. Hernández, and I. Estrella, "Comparative study of the phenolic composition in lentils processed with and without addition of commercial tannase," Journal of Food Processing and Preservation, vol. 33, no. 6, pp. 695-713, 2009.

[119] M. Dueñas, T. Hernández, and I. Estrella, "Influence of the action of exogenous enzymes on the polyphenolic composition of pea: effect on the antioxidant activity," European Food Research and Technology, vol. 225, no. 3, pp. 493-500, 2007.

[120] G. Urbano, M. Löpez-Jurado, J. M. Porres et al., "Effect of treatment with $\alpha$-galactosidase, tannase or a cell-walldegrading enzyme complex on the nutritive utilisation of protein and carbohydrates from pea (Pisum sativum L.) flour," Journal of the Science of Food and Agriculture, vol. 87, no. 7, pp. 1356-1363, 2007.

[121] Q. He, K. Yao, D. Sun, and B. Shi, "Biodegradability of tannin-containing wastewater from leather industry," Biodegradation, vol. 18, no. 4, pp. 465-472, 2007.

[122] S. Kachouri, S. Halaouli, A. Lomascolo, M. Asther, and M. Hamdi, "Decolourization of black oxidized olive-mill wastewater by a new tannase-producing Aspergillus flavus strain isolated from soil," World Journal of Microbiology and Biotechnology, vol. 21, no. 8-9, pp. 1465-1470, 2005.

[123] K. Murugan and S. A. Al-Sohaibani, "Biocompatible removal of tannin and associated color from tannery effluent using the biomass and tannin acyl hydrolase (E.C.3.1.1.20) enzymes of mango industry solid waste isolate Aspergillus candidus MTTC 9628," Research Journal of Microbiology, vol. 5, no. 4, pp. 262-271, 2010.
[124] A. Tejirian and F. Xu, "Inhibition of enzymatic cellulolysis by phenolic compounds," Enzyme and Microbial Technology, vol. 48, no. 3, pp. 239-247, 2011.

[125] C. S. Jun, M. J. Yoo, W. Y. Lee et al., "Ester derivatives from tannase-treated prunioside A and their anti-inflammatory activities," Bulletin of the Korean Chemical Society, vol. 28, no. 1, pp. 73-76, 2007.

[126] R. R. Dykstra, A. T. Brooker, N. P. Somerville Roberts et al., "A catalytic laundry detergent composition comprising relatively low levels of water-soluble electrolyte," U.S. Patent Application No. 2011/0005003, 2011.

[127] D. Banerjee and B. R. Pati, "Optimization of tannase production by Aureobasidium pullulans DBS66," Journal of Microbiology and Biotechnology, vol. 17, no. 6, pp. 1049-1053, 2007.

[128] P. D. Belur and G. Mugeraya, "Microbial production of tannase: state of the art," Research Journal of Microbiology, vol. 6, no. 1, pp. 25-40, 2011.

[129] K. Murugan, S. Saravanababu, and M. Arunachalam, "Screening of tannin acyl hydrolase (E.C.3.1.1.20) producing tannery effluent fungal isolates using simple agar plate and SmF process," Bioresource Technology, vol. 98, no. 4, pp. 946949, 2007.

[130] G. A. S. Pinto, S. G. F. Leite, S. C. Terzi, and S. Couri, "Selection of tannase-producing Aspergillus niger strains," Brazilian Journal of Microbiology, vol. 32, no. 1, pp. 24-26, 2001.

[131] G. Viniegra-González, E. Favela-Torres, C. N. Aguilar, S. D. J. Rómero-Gomez, G. Díaz-Godínez, and C. Augur, "Advantages of fungal enzyme production in solid state over liquid fermentation systems," Biochemical Engineering Journal, vol. 13, no. 2-3, pp. 157-167, 2003.

[132] M. Cruz-Hernández, C. Augur, R. Rodríguez, J. C. ContrerasEsquivel, and C. N. Aguilar, "Evaluation of culture conditions for tannase production by Aspergillus niger GH1," Food Technology and Biotechnology, vol. 44, no. 4, pp. 541-544, 2006.

[133] P. K. Lekha and B. K. Lonsane, "Comparative titres, location and properties of tannin acyl hydrolase produced by Aspergillus niger PKL 104 in solid-state, liquid surface and submerged fermentations," Process Biochemistry, vol. 29, no. 6, pp. 497-503, 1994.

[134] L. P. Ooijkaas, F. J. Weber, R. M. Buitelaar, J. Tramper, and A. Rinzema, "Defined media and inert supports: their potential as solid-state fermentation production systems," Trends in Biotechnology, vol. 18, no. 8, pp. 356-360, 2000.

[135] P. K. Lekha, N. Chand, and B. K. Lonsane, "Computerized study of interactions among factors and their optimization through response surface methodology for the production of tannin acyl hydrolase by Aspergillus niger PKL 104 under solid state fermentation," Bioprocess Engineering, vol. 11, no. 1, pp. 7-15, 1994.

[136] A. Sabu, A. Pandey, M. Jaafar Daud, and G. Szakacs, “Tamarind seed powder and palm kernel cake: two novel agro residues for the production of tannase under solid state fermentation by Aspergillus niger ATCC 16620," Bioresource Technology, vol. 96, no. 11, pp. 1223-1228, 2005.

[137] R. Kumar, J. Sharma, and R. Singh, "Production of tannase from Aspergillus ruber under solid-state fermentation using jamun (Syzygium cumini) leaves," Microbiological Research, vol. 162, no. 4, pp. 384-390, 2007.

[138] B. Treviño-Cueto, M. Luis, J. C. Contreras-Esquivel, R. Rodríguez, A. Aguilera, and C. N. Aguilar, "Gallic acid and tannase accumulation during fungal solid state culture of a tannin-rich desert plant (Larrea tridentata Cov.)," Bioresource Technology, vol. 98, no. 3, pp. 721-724, 2007. 
[139] J. van de Lagemaat and D. L. Pyle, "Modelling the uptake and growth kinetics of Penicillium glabrum in a tannic acidcontaining solid-state fermentation for tannase production," Process Biochemistry, vol. 40, no. 5, pp. 1773-1782, 2005.

[140] I. Darah, G. Sumathi, K. Jain, and S. Lim, "Tannase enzyme production by entrapped cells of Aspergillus niger FETL FT3 in submerged culture system," Bioprocess and Biosystems Engineering, vol. 34, no. 7, pp. 795-801, 2011.

[141] P. K. D. Mohapatra, K. C. Mondal, and B. R. Pati, "Production of tannase by the immobilized cells of Bacillus licheniformis KBR6 in Ca-alginate beads," Journal of Applied Microbiology, vol. 102, no. 6, pp. 1462-1467, 2007.

[142] D. Banerjee, K. C. Mondal, and B. R. Pati, "Tannase production by Aspergillus aculeatus DBF9 through solid-state fermentation," Acta Microbiologica et Immunologica Hungarica, vol. 54, no. 2, pp. 159-166, 2007.

[143] V. Battestin and G. A. Macedo, "Tannase production by Paecilomyces variotii," Bioresource Technology, vol. 98, no. 9, pp. 1832-1837, 2007.

[144] Manjit, A. Yadav, N. K. Aggarwal, K. Kumar, and A. Kumar, "Tannase production by Aspergillus fumigatus MA under solid-state fermentation," World Journal of Microbiology and Biotechnology, vol. 24, no. 12, pp. 3023-3030, 2008.

[145] T. H. S. Rodrigues, G. A. S. Pinto, and L. R. B. Gonçalves, "Effects of inoculum concentration, temperature, and carbon sources on tannase production during solid state fermentation of cashew apple bagasse," Biotechnology and Bioprocess Engineering, vol. 13, no. 5, pp. 571-576, 2008.

[146] G. Dey, A. Mitra, R. Banerjee, and B. R. Maiti, "Enhanced production of amylase by optimization of nutritional constituents using response surface methodology," Biochemical Engineering Journal, vol. 7, no. 3, pp. 227-231, 2001.

[147] S. Sharma, L. Agarwal, and R. Saxena, "Statistical optimization for tannase production from Aspergillus niger under submerged fermentation," Indian Journal of Microbiology, vol. 47, no. 2, pp. 132-138, 2007.

[148] R. B. Naidu, J. S. Subramanian, N. S. Sivasubramanian, D. Selvakumar, and R. Puvanakrishnan, "Optimization of tannase production from Aspergillus foetidus using statistical design methods," Current Trends in Biotechnology and Pharmacy, vol. 2, no. 4, pp. 523-530, 2008.

[149] J. Yao, X. J. Fan, Y. Lu, and Y. H. Liu, "Isolation and characterization of a novel tannase from a metagenomic library," Journal of Agricultural and Food Chemistry, vol. 59, no. 8, pp. 3812-3818, 2011.

[150] A. Sadana, Bioseparation of Proteins, Academic Press, London, UK, 1998.

[151] R. Bhardwaj, B. Singh, and T. K. Bhat, "Purification and characterization of tannin acyl hydrolase from Aspergillus niger MTCC 2425," Journal of Basic Microbiology, vol. 43, no. 6, pp. 449-461, 2003.

[152] B. Mahendran, N. Raman, and D. J. Kim, "Purification and characterization of tannase from Paecilomyces variotii: hydrolysis of tannic acid using immobilized tannase," Applied Microbiology and Biotechnology, vol. 70, no. 4, pp. 444-450, 2006.

[153] S. C. Enemuor and F. J. C. Odibo, "Partial purification and characterization of Aspergillus tamarii IMI388810 (B) tannin acyl hydrolase," Archives of Applied Science Research, vol. 2, no. 6, pp. 290-299, 2010. 

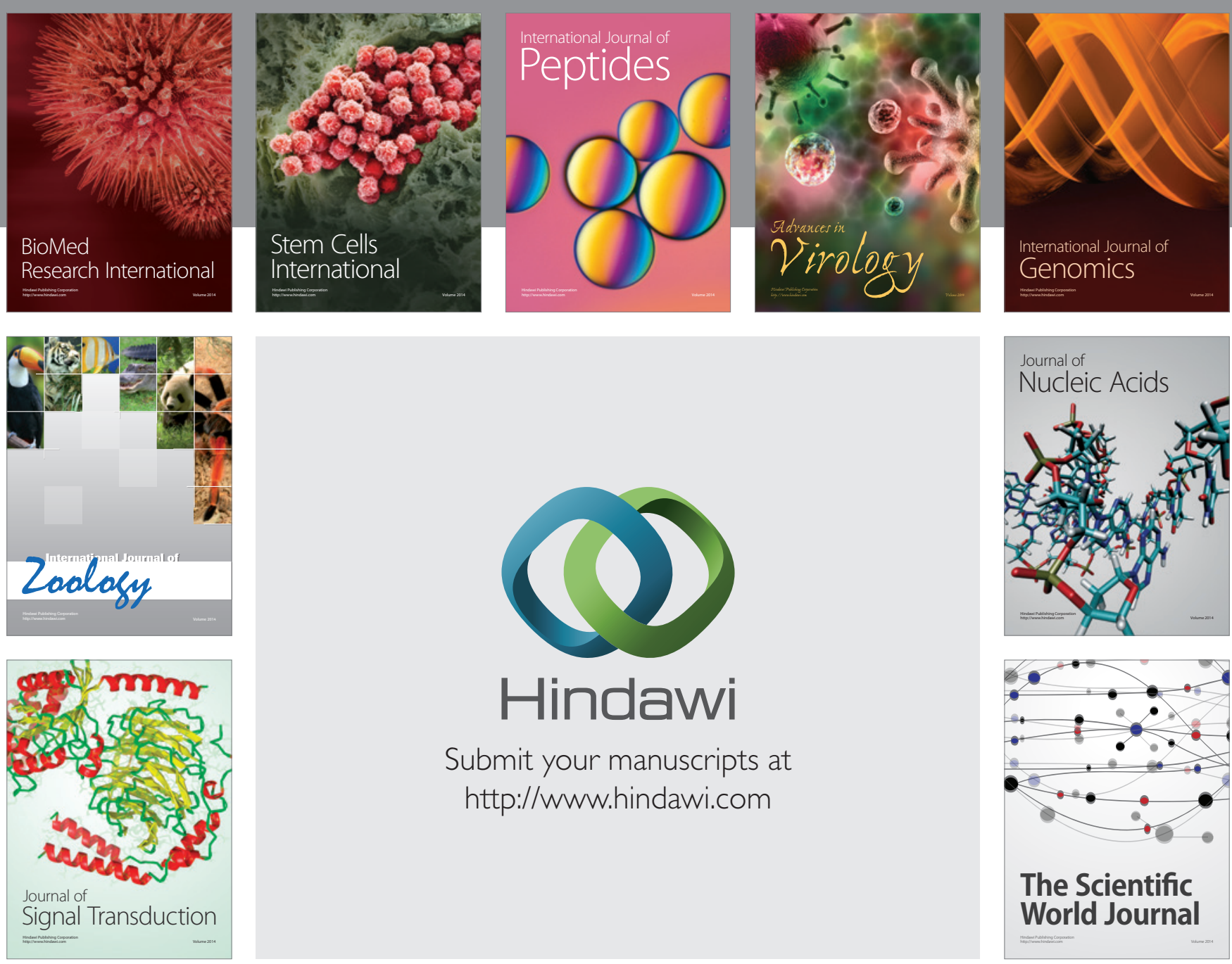

Submit your manuscripts at

http://www.hindawi.com
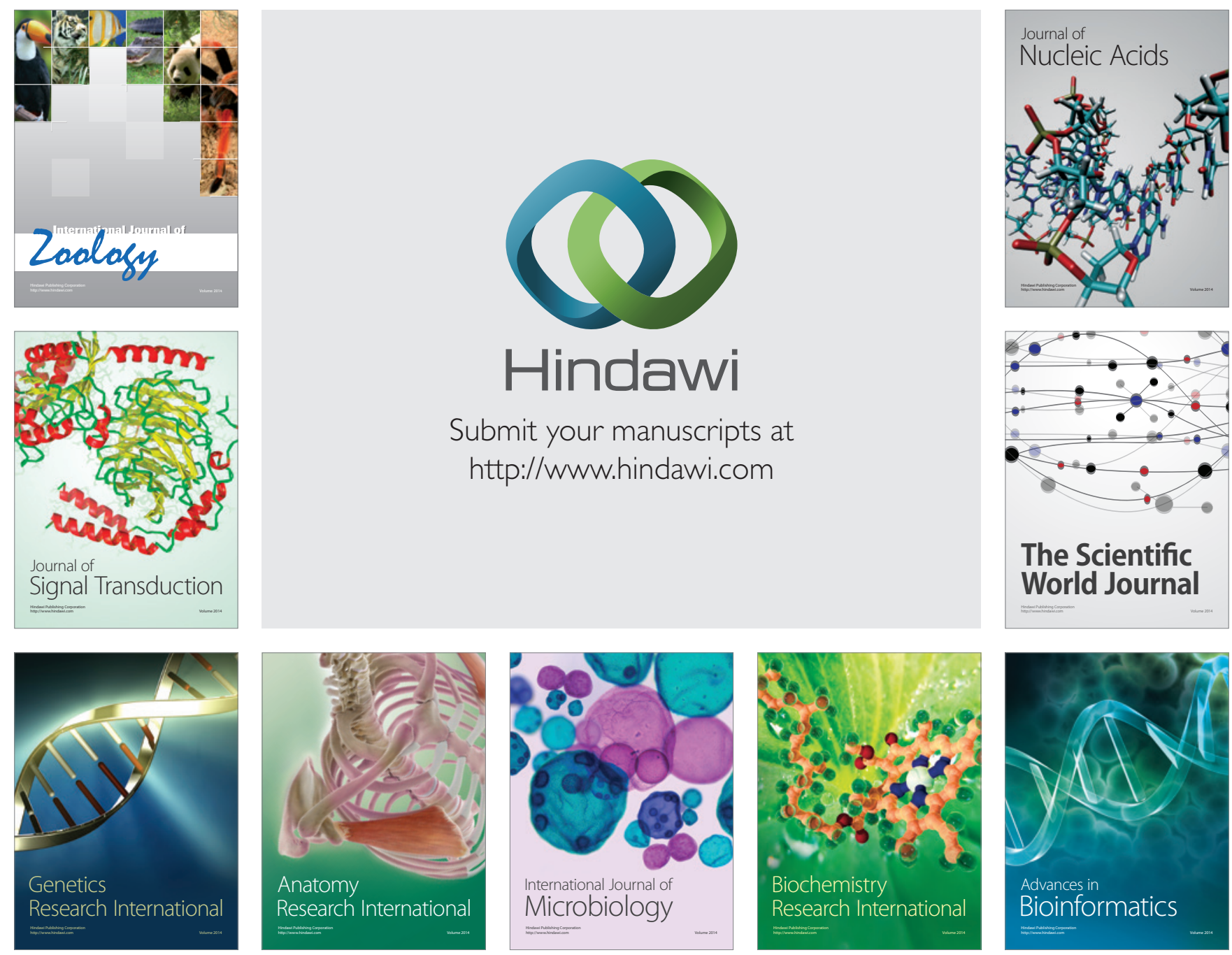

The Scientific World Journal
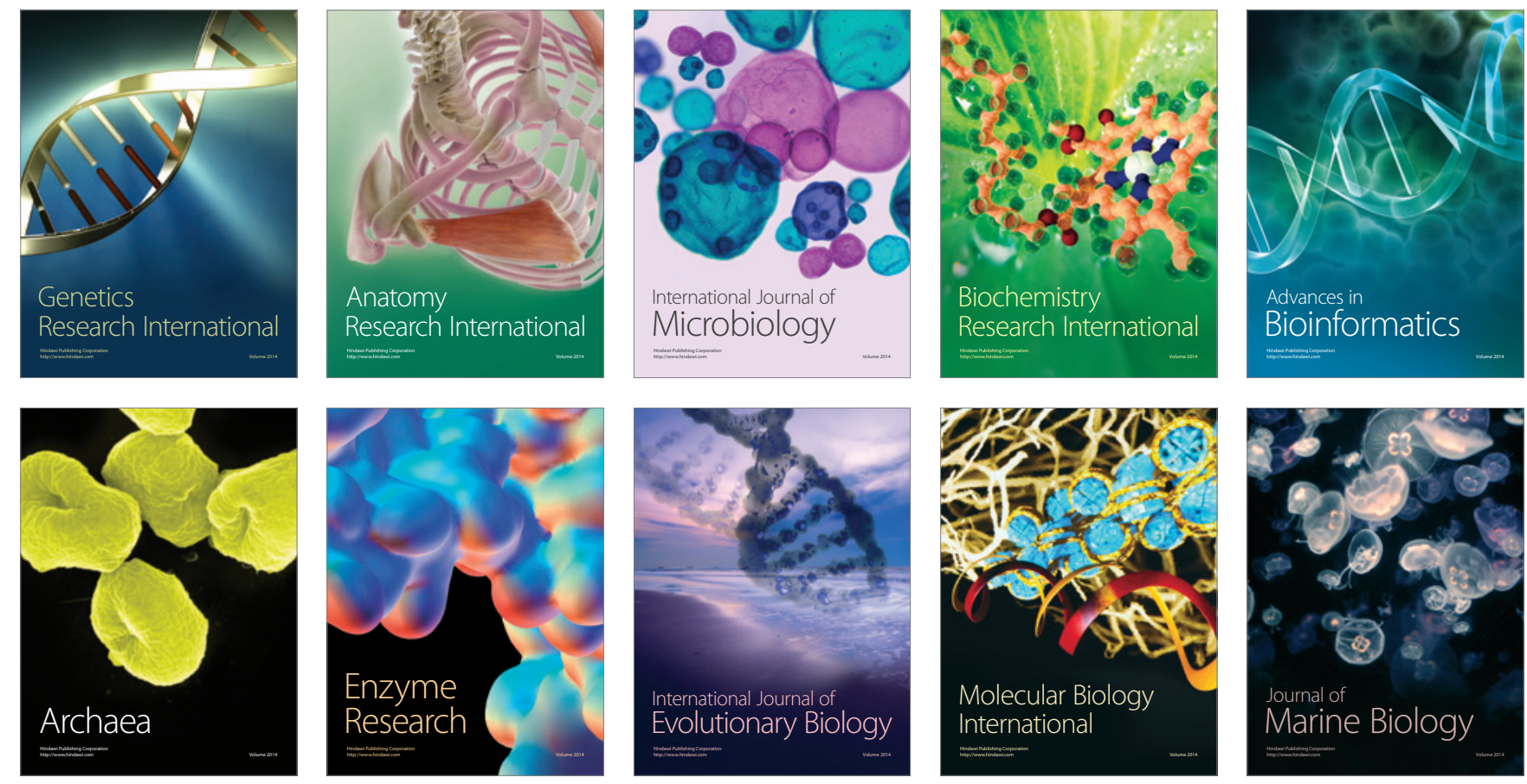